Article

\title{
Universal Open Space Design to Inform Digital Technologies for a Disability-Inclusive Place-Making on the Example of Hungary
}

\author{
Gabriella Szaszák ${ }^{1, *}$ and Tibor Kecskés ${ }^{2}$ \\ 1 Faculty of Landscape Architecture and Urbanism, Institute of Urban Design and Planning, \\ Szent István University, 1118 Budapest, Hungary \\ 2 Department of Residential Building Design, Faculty of Architecture, Budapest University of Technology and \\ Economics, 1111 Budapest, Hungary; kecskestibor@edu.bme.hu \\ * Correspondence: gabriella.szaszak@edu.bme.hu or szaszakg@gmail.com
}

Received: 31 August 2020; Accepted: 5 November 2020; Published: 10 November 2020

\begin{abstract}
This study explores the 'people' and 'place' components of the smart city concept in order to inform its third component, 'technology', for augmented disability inclusion. The research objective was to reveal the capability of the universal open space design (UOSD) method in classifying key spatial factors according to their type of digital applicability as a channel or subject for information and communication technologies (ICTs). Results were derived from three Hungarian design projects presented as case studies, using the research through design (RtD) method. User needs and usage patterns, open space environmental components and types according to their tolerance towards physical modification, and relevant disability-related concepts linked to UOSD were hierarchized and interrelated to digital technologies that can replace or complement the environmental components. Findings were represented in the spatial Maslow pyramid of user needs related to the relevant spatial design concepts, open spaces public services, and digital technologies. The results showed that upper (less basic) levels of the digital Maslow pyramid related to public services other than transport and concepts other than physical accessibility lack digital completion or replacement. In particular, a more detailed and consistent knowledge about spatial-digital interrelations for sensory accessibility should be incorporated into the practical and theoretical background of "smart" UOSD. In conclusion, this paper demonstrates how the combination of the concepts of UOSD and the smart city support a more complex disability-inclusive experience in an interconnected physical, sociocultural, and digital network of open spaces.
\end{abstract}

Keywords: universal design; universal open space design; inclusive urban design; inclusive smart city; landscape architecture; disability; accessibility; Hungary

\section{Introduction}

The evolving concepts of universal design and assistive technologies as key elements for accessibility are highly prioritized concepts in contemporary urbanism and spatial design. Due to rapid urban population growth [1], the importance of inclusive and equal access to open spaces has come into focus [2-8]. The urban demographic changes imply an increase in the number of elderly inhabitants, and as a significant proportion of about one-third of the aging population aged 65 and over is living with some kind of disabilities [9], an aging society means the headcount growth of people living with disabilities (PwD) in urban areas too. In addition, the COVID-19 pandemic in 2020 also showed the importance of accessible, barrier-free urban and green spaces which are safer for work and basic for recreation and social participation. In the city, the dramatically evolving concept of information and communication technology (ICT) has also emerged over the last decades, which influences people's 
social and spatial actions and interactions, and thereby has a significant effect on the patterns of the everyday activities of $\mathrm{PwD}$ too. This research focuses on whether and how the universal open space design (UOSD) approach is capable to inform ICTs about the open spaces' key features and services, which can serve as a basis for the digital layers related to those spaces. This combination of tools can contribute to enriching the citizens' experience and enhance the overall accessibility for creating inclusive smart cities [10-12].

Basic components of the city concept are people who inhabit the city, the urban places which physically form the city $[2,3,7,13]$, and technology as a mediator $[10,14,15]$. Although these components form a unity, their characteristics and interactions can be examined separately. This research aims to explore the potential of the UOSD method in the typology of open spaces' main environmental components and public services through the discovery of these interrelations in order to find their relevance when attaching digital layers to a certain space. In this context, this paper presents the needs and use habits of PwD in relation to the level of access to the physical outdoor environment. Based on the 'people' component, the objects and features of the open spaces' different types, which influence equal access for their users, will be observed and defined with the help of Hungarian case studies. The lessons learned from the observations complete the theoretical background for the first pillar concerning the needs and use habits of PwD. After exploring the interrelations of 'people' and 'place' components, the capability of their attributes to inform technology for augmented, disability-inclusive development will be discussed.

\section{The Structure of the Paper}

In Section 2, a general literature overview is given, organized according topics relevant to the research. The characteristics and environmental aspects of certain disabilities are shown in Section 2.1. Subsequently, design concepts related to disability-inclusive open spaces (Section 2.2), open spaces' public services, and the hierarchy of user needs (Section 2.3) are explored. In Section 2.4, the special consequences in the case of Hungary are presented. The typology of open spaces based on their tolerance towards intervention (Section 2.5) explores aspects necessary for the selection of the case studies. Research objectives are detailed in Section 2.6.

Section 3 gives a detailed overview about the applied research materials and methods.

Section 4 presents the results, starting with three selected case studies, namely downtown Budapest (OS-1, Section 4.1), the Liget Budapest Project (OS-2, Section 4.2), and the Accessible Nature Project (OS-3, Section 4.3). Thereafter, findings relevant to the implementation of universal open space design mediated by digital technologies are explained (Section 4.4).

The research is discussed in Section 5, and findings are concluded in Section 6.

\section{Literature Review}

\subsection{Characteristics and Environmental Aspects of Certain Disabilities}

According to the statistics of the WHO, approximately 15\% of the world's population lives with some type of disability, forming the world's largest minority [16]. Counting their relation- and friendships, and people with temporary changes or lack in ability due to their life situation or life cycle, the population affected by disabilities is an even more significant minority. Children, older people, passengers carrying heavy luggage, wearing high heels, or using earplugs, persons with reduced abilities or disabilities, etc. have diverse accessibility needs with respect to open spaces.

"Persons with disabilities include those who have long-term physical, mental, intellectual or sensory impairments which in interaction with various barriers may hinder their full and effective participation in society on an equal basis with others" [17] (Article 1). For people living with motor (or mobility) impairment physical accessibility is a priority for the environment's safe, independent, and convenient use [18-23]. People living with sensory (visual or hearing) disability, adequate information and communication are the most crucial criteria for being able 
to engage in physical outdoor activities [18-21,24-33]. People living with intellectual and psychosocial (cognitive and/or mental) disabilities need clear, legible, transparent information and a friendly, familiar environment, as it can give the sense of comfort and safety for its users, which is also essential for equal access and usability [18-21,34-36]. Age-related cognitive decline implies environmental needs similar for those living with intellectual disability [21,37,38]. Significant individual components are, e.g., the form(s), the occurrence time, and the duration of the impairment, or the aid used. Besides individual skills, equal access to open spaces and the mode of acting in them is also determined by multiple external factors, such as environmental, economic, legal, social, and cultural conditions [21]. The external environmental factors influencing PwD in the use of open spaces are summarized in Table A1.

\subsection{Design Concepts Related to Disability-Inclusive Open Spaces}

The 'Convention on the Rights of Persons with Disabilities' (CRPD) defines 'accessibility' as the following: "To enable persons with disabilities to live independently and participate fully in all aspects of life, States Parties shall take appropriate measures to ensure to persons with disabilities access, on an equal basis with others, to the physical environment, to transportation, to information and communications, including information and communications technologies and systems, and to other facilities and services open or provided to the public, both in urban and in rural areas" [17] (Article 9). The concept of 'accessibility' is used in the design strategies like 'accessible design' or 'barrier-free design' [1], which imply the elimination of the physical obstacles in the environment. For people living with any forms of sensory disability, tools of 'sensory accessibility' have to be applied for accessible information and communications which support orientation and navigation in the physical spaces $[18,21]$. Key concepts of the discussed environment-focused strategies are independence and safety provided through physical and info-communication accessibility. The obstacles in the physical environment prevent equal social, cultural, professional participation, so enhanced accessibility benefits the whole society $[16,39]$. Inversely, social exclusion becomes manifest in the form of physical barriers in the environment.

To address disability issues in a complex way, a paradigmatic shift has taken place during the last decades. The medical model of disability was replaced by the social model stating that disability is rooted in the society, not in the person or in the environment. In parallel, concepts based on human rights followed the environment-focused design perspectives: new theories have emerged $[17,39,40]$. The strategy of 'universal design' (UD) was created in the USA (cf. Americans with Disabilities Act of 1990) [19], and become one of the two most known design strategies in the world. The other main method is rooted in Europe and called 'design for all' (DfA) [21]. Besides UD and DfA, the term of 'inclusive design' (ID) became the most frequently used term regarding open spaces at the international level [37]. In Hungary, the phrase of UD has spread in urban planning, architecture. and landscape architecture, while ID stands more for interior design. The aims and principles of UD, DfA, and ID are very similar, showing subtle differences only at national levels, and therefore they are often used as synonyms, essentially with the same meaning. According to the United Nations' CRPD "Universal Design means the design of products, environments, programmes and services to be usable by all people, to the greatest extent possible, without the need for adaptation or specialized design. Universal design shall not exclude assistive devices for particular groups of persons with disabilities where this is needed" [17] (Article 2). The certain fields of design adapt and elaborate the general principles of UD for the professional efficiency and interpretability. Concerning open spaces, the principle of 'reasonable accommodation' [17] (Article 2), which implies only necessary and appropriate modification and adjustment, is of increased importance, as the natural components of the outdoor environment are often limited to modification. In the interest of describing the profession-specific aspects of UD for landscape architecture, the concept of 'universal open space design' (UOSD) was introduced in Hungary to customize the common principles for open spaces [6,41]. Key concepts of the mentioned complex 
disability-related strategies are diversity, equality, participation, and inclusion in all aspects of life, including the features and public services of open spaces.

The 'smart city' (SC) concept primarily groups services, decision-making mechanisms, and ICT solutions along the development priorities of sustainability, efficiency, and broad participation. The most common analogous concepts with different terms are 'intelligent city', sustainable city' and 'green city' [42]. In smart cities, ICTs are tools for achieving complex goals like improving the quality and efficiency of public services, involving citizens, and improving the quality of life and developing economically self-sustaining systems [10,42,43]. Regarding open spaces, all layers of their history, context, user needs and use patterns, physical measures and accessible networks, public services, related projects, programs, and events can be loaded into the digital database in different forms and languages, making all information about the place widely available. The 'Smart' concept has the potential to enhance inclusive access, disseminate educational knowledge, provide practical information via applications developed for the Internet and smart devices, contribute to ecological and sustainable operation, etc. The introduction of smart technologies to open spaces can also invite currently underrepresented younger generations [44] to the public places. Moreover, an increase in time spent outdoors contributes directly to the promotion of health and well-being [23,37,45-48]. By exploiting the potential of digital technologies, the extent of physical intervention can be reduced, which in this paper previously was proved of high importance regarding open spaces. Furthermore, the innovative and collaborative solutions driven by ICT empower stakeholders and promise innovative urban planning for creating more efficient, sustainable, inclusive and safer cities [49-51], which significantly benefits the citizens including PwD by supporting their overall participation for example in the use of open spaces' public services [51]. The digital tool of 'mobile assistive technology' (MAT) can contribute to 'sensory accessibility' widely by completing traditional assistive products (white cane, guide dog) with digital technologies like audio maps, tag readers, and GPS navigation with mobile smart systems $[52,53]$.

The combination of the concepts of 'smart city' and 'universal design' creates the idea of 'inclusive smart city', where inhabitants' experience of urban spaces is augmented by the use of digital assistive technologies, fostering the safe and autonomous performance of their everyday activities best suited to their needs [10,12]. The concept of the inclusive smart city is based on collaboration, knowledge about user's needs, and incorporation of ISC principles into the whole process already from the physical design stage $[10,15,51]$. However, in mainstream policies and design practices, people with special needs are not always taken into consideration. When the planning or design phase is not conducted according to disability-related strategies, the retrospective works generate extra costs, provoking opposition among stakeholders towards disability. Therefore, urban development should be shifted towards strategies that are informed about the needs of their diverse population and use tools from the beginning of the processes to enhance social inclusion and participation, to augment equal access to public services and to stimulate economic growth on a sustainable way [49].

Referring to the principle of broad participation, the concept of 'participatory design' has to be mentioned, which emerges directly from the user needs [2,54-56]. The 'people' component of the city (cf. [57]) determines spatial perception, thus the design process-in which the designer is a mediator and not an omnipotent top-down creator-should provide a framework for inclusion based on the cultural and social meaning of the certain place, on genius loci, on the identity of the place's users and their needs. All people - "those with disabilities, and (... ) those that haven't quite found theirs yet" [33]—will be an integral part of such a bottom-up creative process [25,58,59]. In the bottom-up design practices, ICT-enabled design participation can contribute to incorporate citizens into the design process. The bottom-up approach characterized by civic engagement and social activism is often combined with state-focused, but also participation-based, top-down approaches [54].

\subsection{Open Spaces' Public Services and the Hierarchy of User Needs}

The definition of UD refers to products, environments, and services usable for all [17]. The primary public services of open spaces are mobility, recreation, and social life. Outdoor activity has physical 
benefits affecting people's health and life quality positively $[13,23,45-48,58]$. Equal access to social interactions also helps inclusion and social participation. Open spaces are places also to transport, culture, science, work, education, sport, etc. The public services of inclusive open spaces are equally and independently accessible and usable for all. At the same time, most of urban places have formed over centuries and their historic values are limited to physical interventions enhancing accessibility, as are natural components like terrain, topography, vegetation, water surface, etc. Furthermore, environmental components are immanent parts of the open spaces' public services: open places provide not only the frame of an activity, but they form a unity with their users and their activities, i.e., people become a part of the space. From this point of view, every square meter of an inclusive open space is the public service itself.

In consequence, people, society, and places are engaged in a sensitive interaction $[2,13,14,25,33,41,55,57,58]$. The detailed analysis of this complex system of interrelations specifies a hierarchy, i.e., the Maslow pyramid of user needs and usage patterns regarding open spaces. The levels of inclusion move on a scale from physical accessibility to complete inclusion, depending on the individual attributes, the place, and the social context. Physical accessibility has been placed at the bottom of the pyramid, because the lack of it can lead to total exclusion from the use of the environment without assistance. Safety and comfort at the next levels affect the quality of the outdoor engagement, and inclusion stands at the top. At each level, the user's relation to the environment is described by questions:

(1) In the case of physical accessibility providing mobility: "What can I do here?"

(2) In a perceptible, contrasting environment helping orientation: "How can I do it?"

(3) In the case of an appropriate spatial composition improving spatial experience: "What kind of aesthetic experience can I have in this space?"

(4) In the case of a design that is embed in the certain sociocultural context supporting the complete social and spatial experience: "What is this place used for that I can be a part of?" (Figure 1) [41].

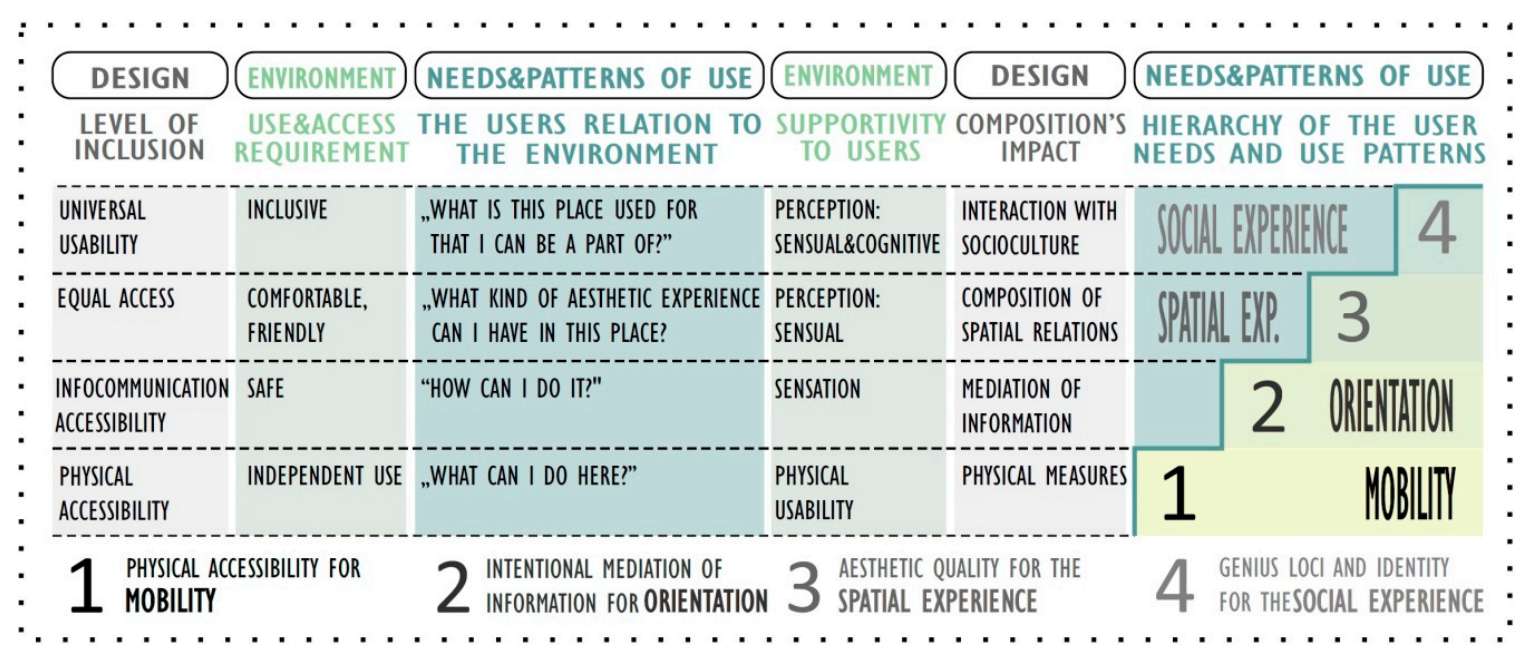

Figure 1. The "spatial" Maslow pyramid of user needs and usage patterns regarding open spaces [41].

The hierarchy of user needs and usage patterns can be related to the basic accessibility needs of PwD concerning the external, environmental factors showed in Table A1. This relation is displayed in Table 1. It can be seen that people with motor and visual impairment have the most basic accessibility needs. People affected by these forms of disability are the most sensitive to the accessibility of the environment, and can be excluded from the use of the space when certain barriers are present. Therefore, if the environment is accessible and usable for people affected by one out of these two disabilities, then it is accessible and usable for all [41]. Understanding the priorities of those living with visual impairment is more difficult as our culture is dominantly visual. Additionally, the aesthetic 
paradigms followed by creative agents often come into conflict with the evolving concept of physical and info-communication accessibility, which completely subordinate form (visual-aesthetic quality) to function, and are therefore hard to be domesticated into traditional paradigms. This "unusualness" can lead to exclusion and intolerance towards disability issues. Spatial designers following their aesthetic-based canons raise the question "What do you want (to see here)?" However, designing with respect towards diversity in mind leads to the question "What do you want to do?" [60]. Without vision people perceive the environment via activity, via movement, via body [60]. Macpherson [59] concludes the same saying visually impaired people experience the space bodily, "via movement, memory and sensations other than sight". Promoting participation is crucial, as it does not take aesthetics as the central point of the process: it focuses on vernacular, spontaneous internal motivations and needs of the community rather than on aesthetically pleasing but exclusive, isolated and overdesigned ideas in order to create livable and overall inclusive cities $[2,54,56,57]$. In summary, knowledge both about visually impaired people's needs and spatial behaviors and about ICT related sensory accessibility is in strong need of expansion, thus they were the special focus of our research.

Table 1. The basic accessibility needs related to the hierarchic levels of the Maslow pyramid of user needs.

\begin{tabular}{ccccccc}
\hline Level & External Environmental Factor & Motor & Visual & Hearing & Cognit. & Elderly \\
\hline $\mathbf{1}$ & Clear pedestrian traffic gauge & $\boldsymbol{V}$ & $\boldsymbol{V}$ & & & \\
\hline $\mathbf{1}$ & Vertical dimensions, slopes & $\boldsymbol{V}$ & & & & \\
\hline $\mathbf{1}$ & Clear space for maneuvering & $\boldsymbol{V}$ & & & & \\
\hline $\mathbf{1}$ & Human dimensions, ergonomics & $\boldsymbol{V}$ & $\boldsymbol{V}$ & & & $\boldsymbol{V}$ \\
\hline $\mathbf{1}$ & Distances & $\boldsymbol{V}$ & & & $\checkmark$ \\
\hline $\mathbf{2}$ & Lighting & $\boldsymbol{V}$ & & & $\boldsymbol{V}$ \\
\hline $\mathbf{2}$ & Contrast & $\boldsymbol{V}$ & $\boldsymbol{V}$ & $\boldsymbol{V}$ \\
\hline $\mathbf{2}$ & Information via multiple channels & $\boldsymbol{V}$ & $\boldsymbol{V}$ & $\boldsymbol{V}$ \\
\hline $\mathbf{3}$ & Well-organized space composition & & & $\boldsymbol{V}$ \\
\hline $\mathbf{3}$ & Diverse, not monotonous spaces & & & $\checkmark$ & $\boldsymbol{V}$ \\
\hline $\mathbf{3}$ & Spaces to emphasize and navigate & $\boldsymbol{V}$ & $\boldsymbol{V}$ & \\
\hline $\mathbf{3}$ & Spaces to connect and separate & & & $\boldsymbol{V}$ \\
\hline $\mathbf{3}$ & Legible, clear, understandable spaces & $\boldsymbol{V}$ & $\boldsymbol{V}$ & $\boldsymbol{V}$ \\
\hline $\mathbf{3}$ & Friendly, aesthetic spaces & & & $\boldsymbol{V}$ \\
\hline
\end{tabular}

\subsection{The Case of Hungary}

This study follows the method of research through design and distills its results from Hungarian case studies. Therefore, it is relevant to have an overview about the Hungarian context of the topic. In Hungary, the Soviet isolation caused a delay in receiving and adapting concepts for inclusion. According to the building act, "the built environment shall be considered accessible if convenient, safe and independent use is ensured for all persons" [61] (2.§ 1). In 2007, a modification of the equalization opportunity law was supposed to shift the attitude to a more general level by extending accessibility to public services and completing barrier-free design with info-communication for complex accessibility [62]. However, this policy has not been integrated to the implementing regulations (cf. [63]), and the focus remained on building construction, and on the accessibility needs of users with physical (mobility) impairments [6]. In Hungary, the disability-related legal background is still focused on physical barriers and buildings, where artificial and therefore better modifiable elements are dominant. In parallel, guidelines and recommendations for compensating mobility impairments, and for accessing public buildings are more detailed. There are international recommendations concerning open spaces (cf. previous chapters), but they are not integrated into the Hungarian legislation - the laws regulate buildings and their environs, are less detailed to urban open spaces, and areas with nature-close conditions are neglected. Inclusive access to open spaces and for a broader range of people with different abilities requires the development and adaptation of Universal Design's principles to all scales and types of the built environment. The deductive, architecture-focused regulation is not valid to open spaces, as their specific components are under-regulated, and architectural components 
are overregulated at the same time. Under-regulation is unable to preserve and maintain landscape architectural values, and overregulation restricts creative processes and degrades the experience of space and nature, generating opposition towards disability. To avoid self-contradictory regulation, the concept of 'partial accessibility' is often used [63] (108. § 11), referring to the principle of reasonable accommodation [17] (Article 2), but using this opportunity to ignore accessibility requirements.

\subsection{Typology of Open Spaces Based on Their Tolerance towards Interventions}

The open spaces' tolerance towards physical interventions is strongly determined by the proportion of their artificial and natural elements, as the natural environmental components can be limited to modification. According to this proportion, three main open space types with a significantly different character can be distinguished:

(1) Public urban open spaces (OS-1) are typically dominated by artificial components, such as streets, squares, and environs of buildings from Balogh's [7] urban open space typology. Its primary public function is transport and mobility, creating a network in the city connecting its public services. Because of the dominancy of its artificial components, this open space type is the most flexible to modification, so regulations for the built environment's accessibility is valid to the greatest extent among open spaces. Furthermore, the smaller the design scale is, the more physical interventions to the environment can be carried out, which means that the recent Hungarian regulation can be best put into practice in the environs of public buildings.

(2) Urban public green spaces (OS-2) include public parks, institution gardens and thematic urban open spaces from Balogh's [7] urban open space typology. It consists of both artificial and natural elements, and the natural components are also often modified, reflecting the urban scales and the strong human influence, creating "domesticated" nature in settlements. Urban green spaces form biologically active areas suitable for recreational activities. Their public services are essential for the city and its inhabitant physiologically and psychologically as well. As the natural atmosphere is inherent in these spaces, physical interventions for accessibility have to be applied carefully. Near buildings and close to intensive, more artificial parts a higher level of physical accessibility can be required. For optimal spatial solutions of equal access, a hierarchy of functional units (e.g., play, sport, passive recreation, events) and connections are recommended to be distinguished.

(3) Semi-natural landscapes (OS-3) — urban woodlands and waterfronts in Balogh's [7] typology—are characterized dominantly by natural environmental components. Like urban green spaces, they are biologically active, are important for humans from psychological and physiological aspects, and can host activities of recreation. As they have the highest proportion of natural environmental elements which often cannot be modified at all, they have the lowest tolerance for physical interventions which can be basic for equal human access, and this trait can limit the applicability of UOSD's tools [41].

\subsection{Research Objectives}

The primary goal of this study is to explore whether and how the method of UOSD is capable to typify open spaces' key environmental components and public services to those the ICT's digital layers can be attached. In this context, the research aims to explore the interrelations between the open space's type (based on its tolerance towards physical modification), public services, and the level of ICT's applicability. This research explores the possibilities of the digital completion or replacement of the environmental components and their contribution to a more disability-inclusive development.

\section{Materials and Methods}

The basic components of the city concept introduced in Section 1 were 'people', 'places' and technology' $[10,14,15]$. Because of its combined character, the subject of this research cannot be 
completely measured with technical instruments, but the incorporation of 'human subject research' involving PwD is also necessary. Therefore, the research was conducted following the integrated, multi-instrument approach of the 'Research through design' (RtD) method, which applies spatial design in a systematic exploration for generating practical-productive and theoretical knowledge [64]. Different types of RtD method were combined:

- 'Research for design' was used in the form of a comprehensive scientific literature review in order to gain knowledge which can serve as an input for universal open space design.

- With the tools of 'Research on design' (or 'design research'), disability-related design strategies and concepts-shown in Section 2-were explored through the analyses of different projects and plans for creating a basis for future design.

- The processes of universal open space design were understood and identified along the method of 'research about design' through observations, site visits, on-site, and follow-up informal oral and written consultations with PwD and their advocacy organizations.

- ' 'Research through design' was applied in real Hungarian design projects in which the authors of this paper were involved. These multiple design experiments are presented as case studies in this paper. Via the analysis of the collected data, UOSD typologies and design principles were derived and continuously updated based on the feedbacks from social participation and monitoring [41,64,65] (Figure 2).

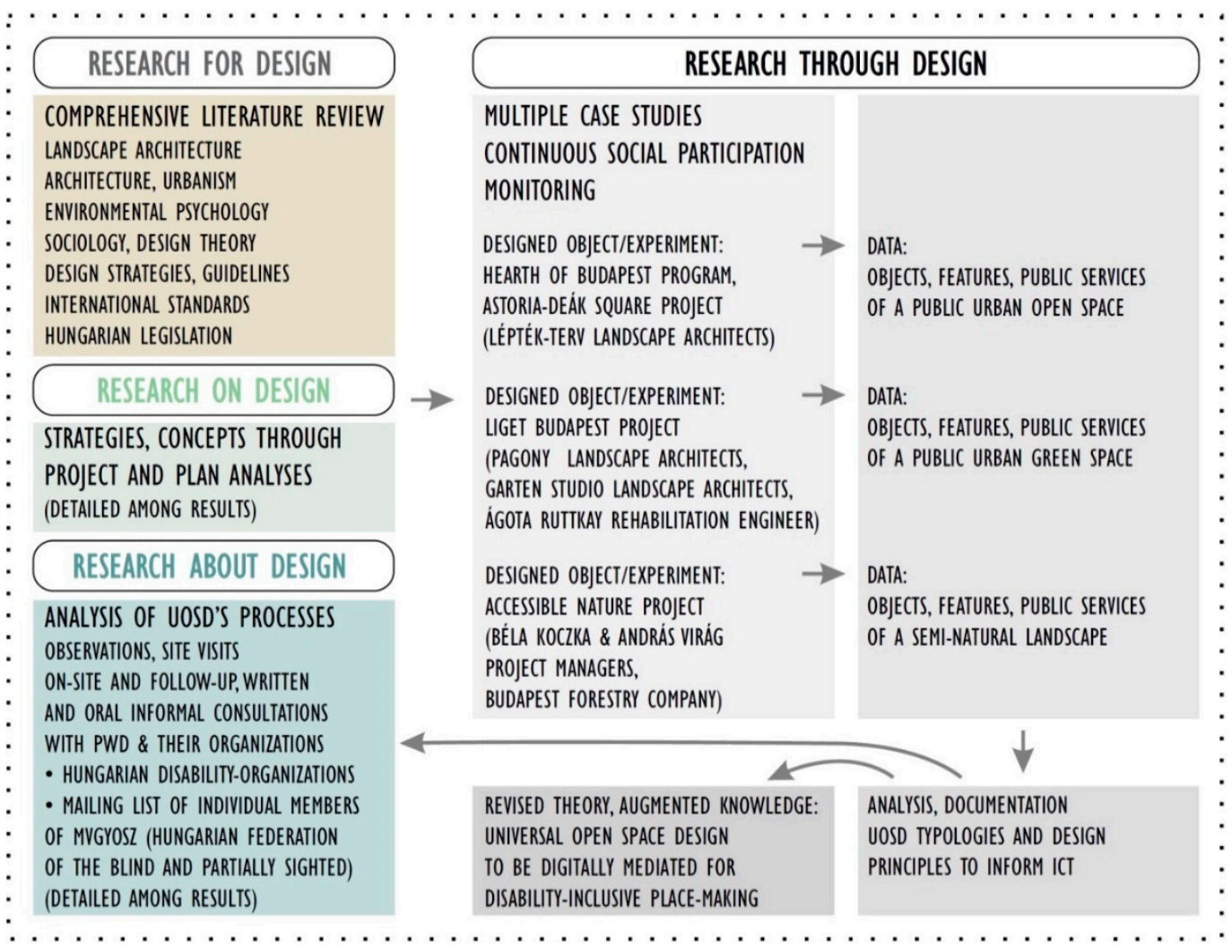

Figure 2. The process of Research through design $[41,64,65]$.

'Research through design' was conducted via three own design projects presented as case studies, based on Francis' methodology [66]. The selection of the case studies was based on the type and scale of the projects. Each project represents a different type of open space based on its tolerance towards interventions (cf. Section 2.5). All three projects had to be designed according to the principles of Universal Design. Part of a complex city-center renewal, a historic urban park, and a national forest unit were selected. The projects were explored along the following aspects: 
- Context, project background, and history.

- The preliminary research and design process.

- Research through design (the design process itself, presented according to classified environmental components namely objects, features, and functional units).

- $\quad$ Significance and uniqueness of the project.

Although the presented development projects faced their unique challenges, they were meant to provide generalizable lessons about the possibilities, limits, successes or fails of UD strategy's implementation related to digital technologies, in order to augment the practical and theoretical knowledge towards inclusion.

\section{Results}

The results of this study are derived from design projects from the authors' own practices. These projects belong to different project types and show variance in scale. The spatial experiments are the examples of a complex city-center's renewal, a historic urban park's rehabilitation, and a disability-focused innovation planned for a national forest. Key selection criterion was the requirement to follow the principles of UD during the design process. In Hungary all three projects were pioneer in this aspect. These projects were among the first ones which incorporated accessibility experts into the interdisciplinary design teams, and involved the organizations of $\mathrm{PwD}$ into the design phrase.

\subsection{Case Study for the Category 'Public Urban Open Space': The Downtown of Budapest}

\subsubsection{Context, Project Background and History}

The heart of Budapest, i.e., the historical core of Pest is a dense and frequented urban fabric. By the turn of the 20th century, the technical condition of public areas in the city center had deteriorated sharply, and both its cityscape and its use were largely determined by the priority of motorized traffic. The general appreciation of the region and the redefinition of the architectural and open space character were the key concepts of the urban development programs of Budapest. To achieve these goals, a medium-term urban development program named Podmaniczky Program was elaborated. Within the frames of the Hearth of Budapest Program, an ideas competition was mentioned for the complex renewal of the downtown on three action areas: (1) bridges and the new Pest promenade, (2) representative gateway, and (3) new boulevard of the downtown [67].

Authors contributed to the design process of the Károly Boulevard belonging to the 2nd action area. It is the northern part of the inner ring of the Small Boulevard in Budapest. The planning started in 2008. Landscape architecture was conducted by Lépték-terv Landscape Architects [67]. Authors were invited to the design team in 2010, in relation to a master's theses research in the field of rehabilitation engineering [68]. Among the design objectives of the project, priority was given to safety, security, and accessibility ("wall-to-wall pavements, flat ground surfaces, safety camera system, multi-level information, communicating streets") [68]. In general, the functional approach for creating inclusive spaces, and the aesthetical approach for renewing cultural and historical values appeared in parallel during the design process.

\subsubsection{The Preliminary Research and Design Process}

'Research for design': Literature review has been done continuously in the research topic. Related references are detailed in Section 2.

'Research on design': The complex renewal of the Budapest downtown started earlier with the new Pest promenade between the Comedy Theater and Kálvin Square, and the southern and central parts of the Small Boulevard [67]. Available plans of the new Pest promenade were examined [69] and compared with the users' feedbacks about the realized plans. 
'Research about design': In relation to the project, site visits have been carried out since 2010 in the Hungarian capital and to several European cities to compare different technical solutions of open space design and their details related to UD. (The thematic photo documentation about these site visits can be observed in Szaszák's PhD theses: Appendix MIII/1—Science photo library of Universal Open Space Design's international examples (cf. [41])).

Since 2009, consultations with several individual members and representatives of the Hungarian Federation of the Blind and Partially Sighted (MVGYOSZ) has been continued. Members who were interested to participate in testing the solutions which were applied to renewed open spaces were added to the civil accessibility group of MVGYOSZ. Professionals from several related fields (e.g., architects, landscape architects, rehabilitation engineers, civil engineers, legalists, special educators, medical doctors) and people living with visual impairment changed information via the informal channel of the 'Accessibility Group's mailing list. The distilled lessons were fed back to the actual phases of the project [70]. Tactile pavements were intensively tested and researched, as these technologies were new to Hungary at that time. The introduction or update of info-communication technologies at smart bus stops and pedestrian crossings also were in the focus of the design [6].

\subsubsection{Research through Design}

Concluded from the preliminary research for design, the primary public service of urban open spaces is to provide space for traffic. Inviting, friendly and alive squares and places invite also social activities. Recreation is more connected to the green infrastructure, but an inclusive urban open space can be suitable also for passive and active recreational activities [2]. Károly Boulevard is affected by heavy motorized traffic, so recreational activities are more attracted to nearby parks (e.g., Erzsébet square and Gödör), and the area's dominant function is transportation. Environmental components affecting the accessibility and usability of public urban spaces are categorized in Table 2. In the following section, the design project's program elements will be discussed along these categories.

Table 2. Environmental components in the focus of research and design concerning public urban open spaces (OS-1).

\begin{tabular}{|c|c|}
\hline Category & Item \\
\hline General aspects & universal access to public services \\
\hline Walking surface & surface, material, drainage \\
\hline Street furniture & $\begin{array}{l}\text { general requirements: surface, material, ergonomics } \\
\text { bench, table, drinking fountain, litter bin, information board, pavilion, etc. }\end{array}$ \\
\hline \multirow{3}{*}{$\begin{array}{l}\text { Bridging structures } \\
\text { and railing }\end{array}$} & stairs \\
\hline & ramp, slope \\
\hline & handrail, bollard, traffic-directing structures \\
\hline Vegetation & plants \\
\hline \multirow[t]{5}{*}{ Info-communication } & orientation: contrast in light and color, tactile signage \\
\hline & navigation: direction signage \\
\hline & information: maps, functions \\
\hline & communication: audible support \\
\hline & lighting \\
\hline \multirow[t]{5}{*}{ Functional units } & general requirements, approaching, network, buildings \\
\hline & streets, squares \\
\hline & pedestrian crossings \\
\hline & car parking \\
\hline & stops of public transportation \\
\hline
\end{tabular}

For creating inclusive spaces, we investigated the different textures of the walking surfaces, the materials' qualities and contrast in light and color, the drainage, the terrain conditions, and used the findings in the design process. Natural stones were laid on the new Pest promenade, and a more cost-effective concrete paver block called "K-stone" was developed for the sidewalks and squares of Small Boulevard [6,67]. 
Street furniture was selected to fulfill requirements of ergonomics and accessible usability. The placement, the dimensions, the quality of materials, the usability and the accessibility of the street furniture already present in the downtown was investigated to find the best fitting products. On the new Pest promenade a unique design product group was used with a special edgy and skew character (Figure 3) which turned out to be undetectable for visually impaired walkers, and therefore not safe enough - therefore on the Small Boulevard this subgroup of street furniture was avoided. In summary, it can be stated the street equipment on the central and southern parts of the Small Boulevard are proper for equally accessible use in the area.

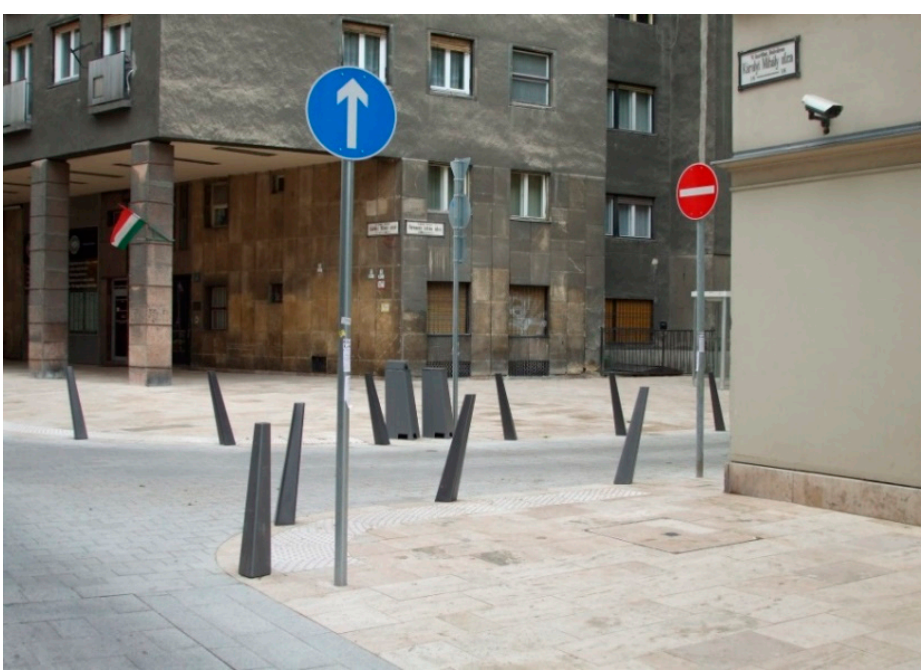

(a)

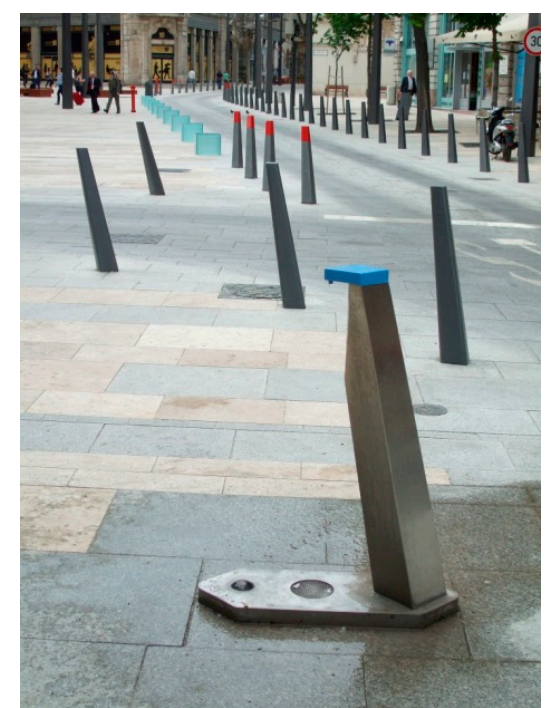

(b)

Figure 3. (a,b) Skew and edgy, and therefore hardly detectable and dangerous street furniture on the new Pest promenade. Tactile pavements on the new Pest promenade show no visual contrast to the limestone pavers of the sidewalks, as they were designed from the same limestone material.

The project area is relatively level, so no stairs were required. (On other parts of the downtown, top landing of stairs had to be signed with warning Tactile Walking Surface Indicators (TWSI) according to MVGYOSZ.) Near the facades of the adjoining buildings, the relevant differences in level were bridged by slight slopes integrated to the sidewalks, rather than by ramps. Wheelchair-accessible cross slopes were provided. Preferring ramps and slopes to stairs offered a more inclusive solution, because stairs are barriers to people with motor impairment, and in general, sloping terrain is more inviting for people [2].

For helping orientation, the consequent use of colors and materials related to certain functions is recommended. In the downtown of Budapest, a wide range of natural and artificial stones could be found. During the design process and realization of the fourth metro line in Budapest, a need for a uniform Budapest pavement has occurred. The developed concept has already been used as a basis for the planning of the city center. Natural stones were laid on the new Pest promenade, and "K-stone" concrete pavers on the Small Boulevard [6,67]. The harmony and consistency of forms and materials is not only important from an aesthetic point of view, but also a basic tool of UOSD: it helps visually impaired walkers to find their way: walkways are always marked by the same material, and people do not have to find out in every situation whether and what the pavement pattern is trying to mediate. In the action areas of the Heart of Budapest Program, the different functions as utility lanes, squares, pedestrian traffic lanes and crossings have been consistently separated in pavement (Figure 4). During the design process of our project, universal open space design was applied to support accessing information and communication via multiple senses. The sensitive hierarchy of spaces with different primary functions also contributed to the better and safer orientation in the space (cf. Table A1, Table 1). 


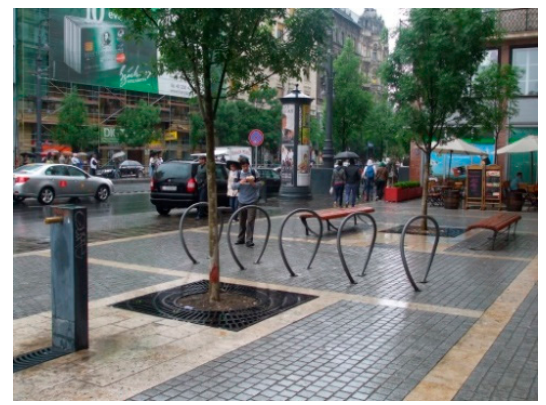

(a)

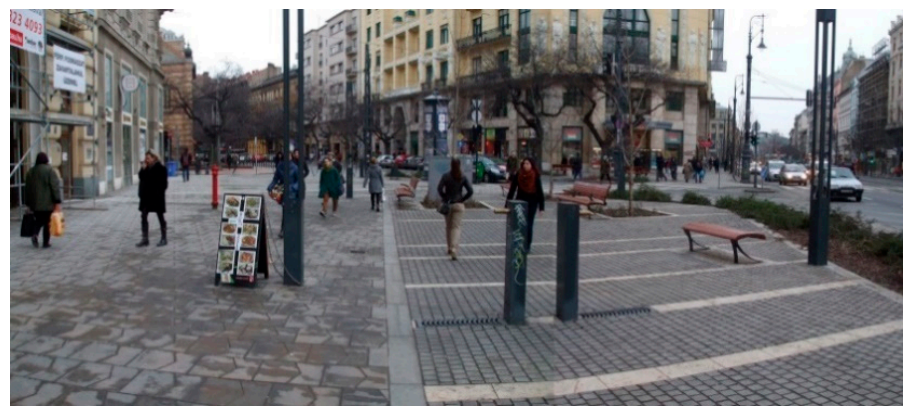

(b)

Figure 4. Contemporary street furniture on Károly Boulevard. Within the renewal process of the Astoria-Deák square section of the Károly Boulevard, different functions as utility areas, squares, pedestrian traffic zones and crossings were differentiated in the type and texture of the pavements. (a) Utility zone at Astoria (b) Square at the crossing of the Small Boulevard and Dob street.

The tactile pavements (tactile walking surface indicators, TWSI) have been new to Hungary when the designing and the construction of the Small Boulevard renewal started from the southern end. A continuous monitoring was carried out with the participation of Hungarian Federation of the Blind and Partially Sighted, who developed their recommendations through their experiences [31]. Following the newest guidelines, solutions proved to be deceptive were corrected (Figure 5).

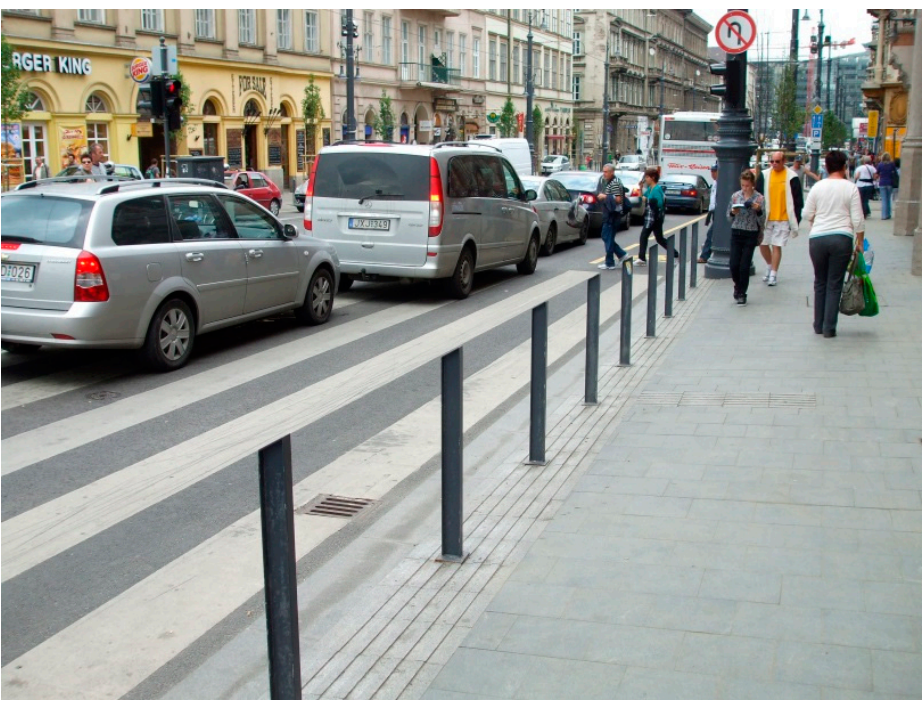

(a)

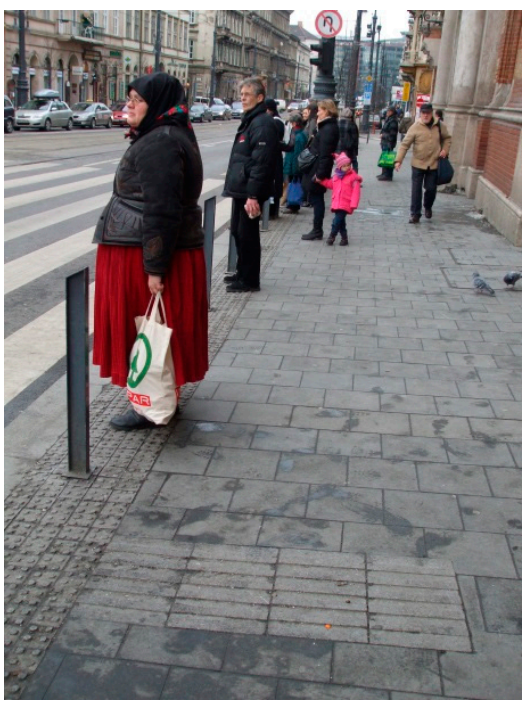

(b)

Figure 5. The mistakes were corrected on the Small Boulevard after the evolving recommendations of the Hungarian Federation of the Blind and Partially Sighted. (a) Guiding pattern at crossings were deceptive, (b) and therefore was changed to a warning tactile at Fóvám square.

Tactile pavers of the new Pest promenade are unique limestone elements designed for the certain site. At the request of the Hungarian Federation of the Blind and Partially Sighted, the warning tactile pattern's flat-topped blisters were arranged diagonally, and not in a square pattern in order to be more different from the guidance tactile. The tactile elements are made in several sizes to be suitable for following the arcs as well. The pavers themselves are identical in material to the pavement of the walkways, so they provide no visual, but only tactile contrast (see Figure 3) — the adequacy of this solution needs further testing.

On Károly Boulevard, a unique tactile signaling system suitable for the regular concrete blocks was designed, but during the construction, high-contrast (white) precast concrete elements used 
on previously renovated parts of the downtown were laid on this part of Károly Boulevard too, partly for financial reasons and partly at the request of stakeholders [6] (Figure 6). Based on a number of subsequent feedbacks, these elements proved to be slippery, and they need regular cleaning to preserve their visual contrast as they get dirty quickly. A continuous, consequent TWSI system was designed and agreed with MVGYOSZ, as this system together with other natural guiding elements (e.g., Contrasting Walking Surface Materials (CWSM), curbs, facades, landmarks) could provide the basis for audio maps.

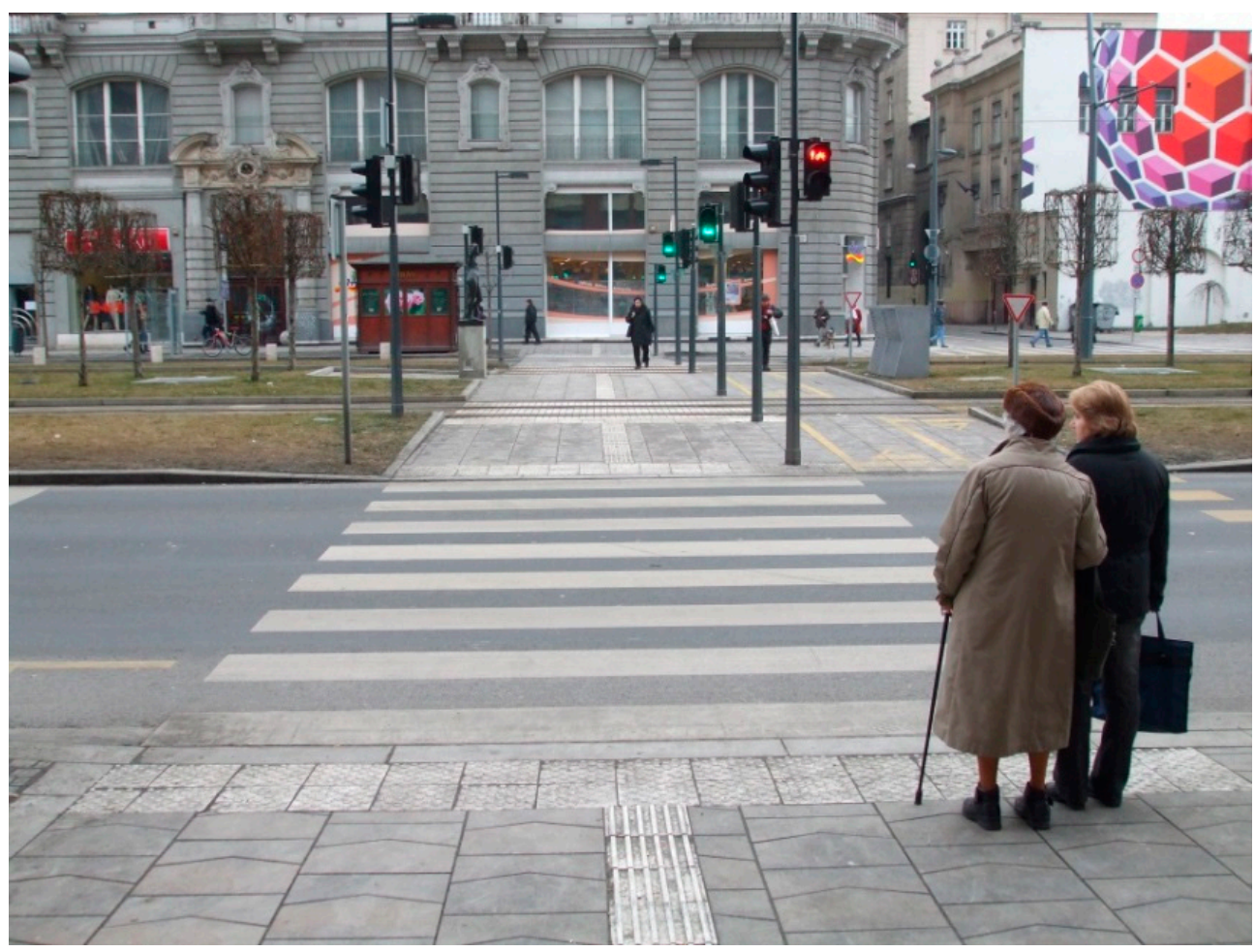

Figure 6. Tactile pavements on Károly Boulevard (part of Small Boulevard).

For the proper perception of the environment, lighting is essential too. Artificial light proved adequate in the area, except for a smart innovation at the section of Károly Boulevard between Dob street and Deák square, where lights were reduced during the night to avoid disturbance of the local inhabitants, but the feedbacks report wrong visibility which weakens the sense of safety.

As a general principle regarding the accessible pedestrian network of urban functions, the importance of the continuous travel chain was emphasized among the key recommendations of UOSD. During a design meeting it was highlighted by a representative of MVGYOSZ, that the presence of public toilets is of great significance, and they have to be signed in the pavement using TWSI for visually impaired passers. In the followings, buildings and edifices related directly to the public services of open spaces will be mentioned among general principles.

For designing inclusive sidewalks and squares with accessible resting functions, investigations were made on the characteristics of the walking surfaces and curbs, the dimensions for maneuvering, the accessible network of routes also to adjoining areas, and the tactile paving. Our findings were that even the main track of flowing pedestrian traffic is often restricted, mostly by mobile street furniture, subparts (e.g., stairs) of buildings, and people using fix street furniture or edifices placed too close to the main track. To ensure the flow of pedestrian traffic on the sidewalks, the street furniture is installed in groups, outside the track of travel (see Figure 5). The types, the placement and the proper dimensions of tactile pavers were still uncertain at the beginning of the comprehensive development program, but the continuous monitoring of their use helped developing the guidelines. On the Astoria-Deák 
square section guiding patterns started to begin immediately when leaving the facades of the buildings to help keeping direction for people living with visual impairments. Previously renewed parts of the Boulevard were corrected after this example (see Figure 3). Also, this section was the first where tactile surfaces guided the users to every important public service, e.g., resting areas, public toilets, etc. (Figure 7).

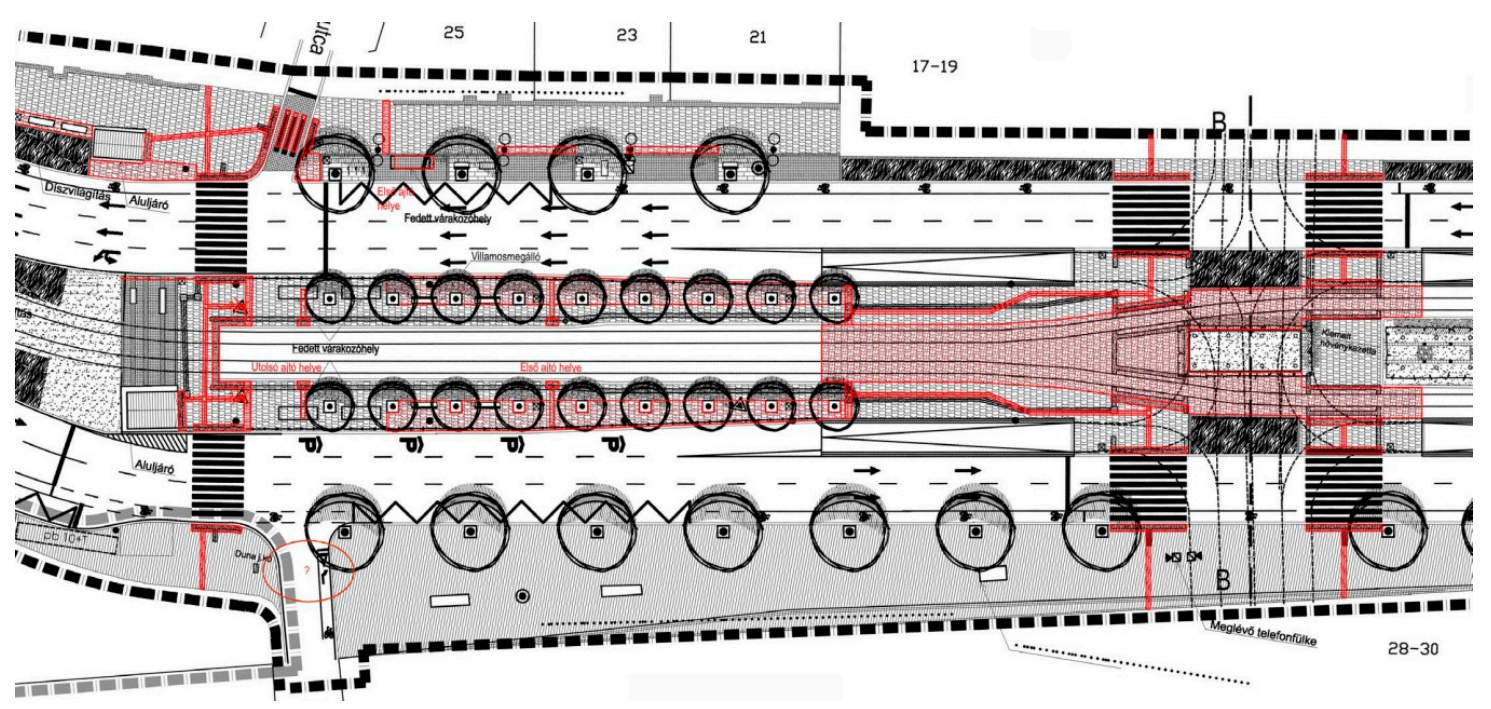

Figure 7. Different functions were displayed in the pavement, helping orientation. Plans have continuously been corrected after the evolving recommendation of MVGYOSZ. The accessibility plan dealt primarily with the tactile signage system. [Part of the accessibility plan by Szaszák].

People living with mobility impairment need low curbs and curb ramps at pedestrian crossings. At the same time, this moderate difference in level is undetectable for visually impaired passers, thus crossings have to be signed with tactile warning lanes. In our project, every crossing was designed wheelchair-accessible and indicated with tactile pavement following the Hungarian recommendations [31]. It has been seemed a general problem that tactile details are hard to interpret during the construction, and the plans are not correctly followed (as shown on Figure 8). Bollards visibility is also poor, especially when the street is crowded, thus bollards were used only when really needed. Audible traffic signals at pedestrian crossings could be activated by a button on the traffic light columns at the edge of the crossing. Earlier, continuously operating audio signals were used at some parts of the city, but new standards recommended noise reduction by mechanically controlled operation only when PwD were present. Tactile guidance was placed in the center axis of the crossings in order to reduce uncertainty of navigation while crossing the road. However, this way, the guiding lane avoided the columns on which the operator panel with the button was placed-hence the idea of a universal mobile smart operator device occurred, but has not been realized so far [71].

Wheelchair-accessible car parking was a special task in the narrow streets of the downtown of Budapest, as physical measures could not be always fulfilled. In the case of Károly Boulevard, the place for motorized traffic was narrowed, and car parking was not allowed along the road. At the same time, narrow sidewalks were designed wider, and a few accessible car parking places could be installed at the edges, connected to the road.

The stops of public transportation were designed according to the exact type of the vehicles used. Even nowadays, most buses and trams in the area are not wheelchair-accessible. For visually impaired people the place of the first door is signed in the pavement with tactile surfaces, but this solution is not always usable in integrated stops where several vehicles can stop simultaneously. The attitude of the society is also an important factor (personal assistance, careful drivers). Another supportive tool was 
the installation of smart stops for the public transportation, provided by smart panels, ticket machines, electronic timetables, and combined with an application for smart devices.

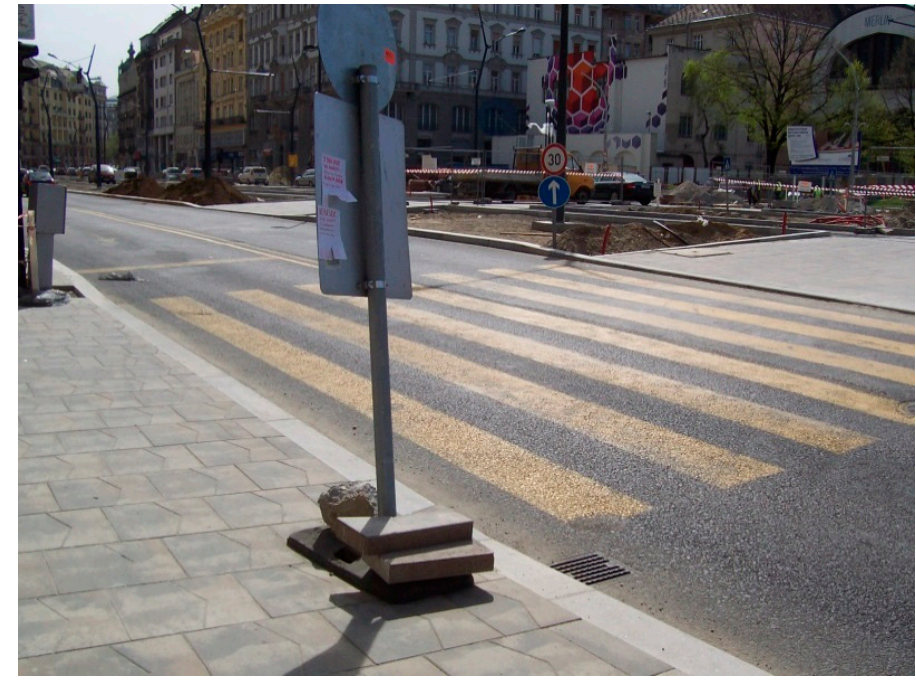

(a)

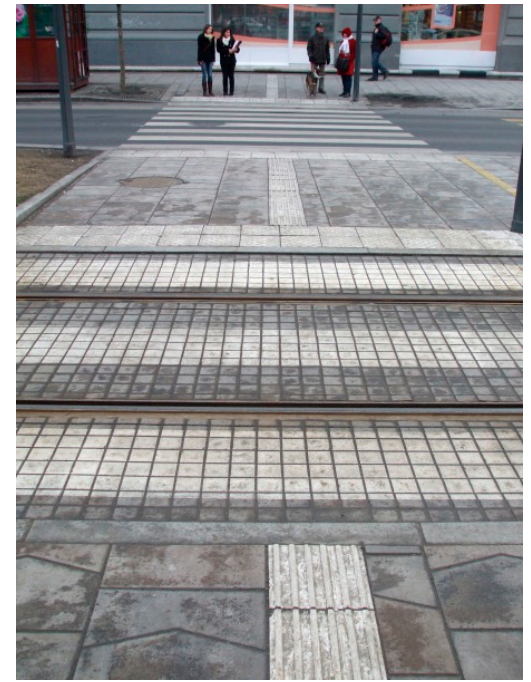

(b)

Figure 8. During the construction, plans are not always followed. (a) Missing tactile warning at a pedestrian crossing on Károly boulevard (b) Plans were not followed correctly: guiding surface does not end in a warning surface, but leads to the railway directly.

\subsubsection{Significance and Uniqueness of the Project}

In summary it can be concluded that creating inclusive open spaces was a priority during the renewal projects in the downtown of Budapest. The basically top-down design process employed the principles of UOSD, and invited the organizations of PwD to the project. The success of the renewal is shown in the feedbacks of the users living with disabilities, and in the honor that the Small Boulevard's design between Astoria and Deák square was awarded with the 1st prize for "Good practice of Universal Design" (cf. [70]). At the same time, aesthetic concerns were raised about the project, mainly due to the appearance of tactile pavements which are unusual and hard to integrate into our recent paradigms. Concerning construction works, plans with these new elements seemed complicated to follow (cf. Figure 8). The bad quality of construction and the lack of fund also delay the evolution of more inclusive open spaces. The needs of people living with visual impairments are less known even nowadays. Their advocacy institutions need time to test solutions and elaborate recommendations, while adapting but not receiving the European and other international technical standards. The cooperation and continuous communication between designers and disability organizations proved to be essential as well, because feedbacks are basic for creating equally accessible open spaces. The use of smart technologies also was introduced.

\subsection{Case Study for the Category "Public Urban Green Spaces": The Liget Budapest Project}

\subsubsection{Context, Project Background and History}

The Budapest City Park (more recently called Liget) is one of the first public parks in the world. At the turn of the 19th century, the New Town Forest, despite its unconstructed wilderness, was popularly visited by city dwellers for walks or excursions. In 1813, an international design competition was announced for the arrangement of the area, which was realized in the English landscape garden style based on the plans of the winner of the competition, Heinrich Nebbien. [72,73] (Figure 9). Throughout its 200-year history, the park has undergone a continuous transformation and has become home to many cultural, recreational and entertainment institutions. By the turn of the 21th 
century, an urgent need for complex park rehabilitation occurred. The primary goal of the renovation was to preserve and present historical values, as well as to sensitively and carefully rethink spatial relations to meet the needs of contemporary park users. To this end, comprehensive surveys and studies have been carried out in all related disciplines, seeking to involve the widest possible range of society, from decision-makers, to designers, to the civil sphere [74].

In 2013-14, the Department of Open Space Design of Corvinus University of Budapest (BCE) mapped the uses of the park via on-site surveys and online questionnaires by recording the activities of 34,733 visitors and processing 1018 questionnaires. The results show that respondents are unanimously satisfied with the park, do not want deep, structural changes or new features-their criticisms are more about the conditions of current park uses and functions. Better quality of walking surfaces, more park furniture and more green space are among the basic needs. The main values of the park are considered to be silence, tranquility, naturalness, and old vegetation. The most common activities are walking, meeting friends, and visiting the Budapest Zoo and Botanical Garden. The contemporary park use patterns show the need for modern infrastructure, adequate number of public toilets, and also the use of digital technologies [44]. In summary, the main purposes of the park visit are active and passive recreation, social contact, and the use of institutional services.

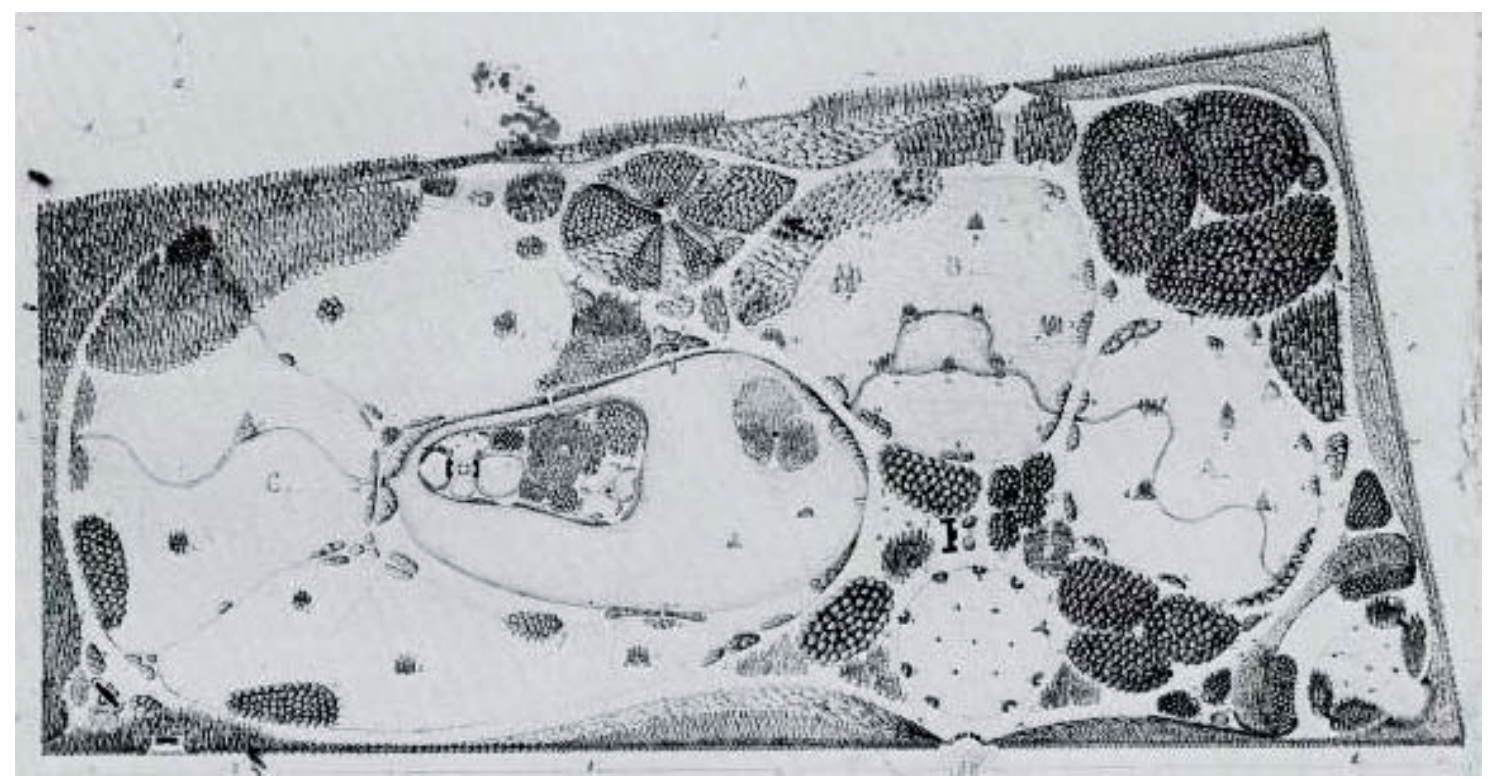

Figure 9. Conception plan of the Budapest city forest by Heinrich Nebbien, 1816 [72] (p. 23).

According to the research of Fekete et al. [75], the park use habits of English landscape gardens have changed little since the first design. Nowadays, the recreational potential is the primary one, only the emphasis has shifted somewhat, partly with the global population growth in cities: leisure activities and nature's role in health and human well-being have come into focus (Figure 10). The shift can also be seen in the perception of the hierarchical system of promenades and paths, which goes beyond the aesthetic quality of the spatial composition: the routes also have the task of exploring the functions and attractions of green spaces. At the same time, it can be said that the 200-year-old Paxton design principles are still valid today and can be applied, while keeping in mind the shift in emphasis. Adapting nature and ensuring sustainability are also in line with the primary goals of renewal, and they also promote naturalness, which is considered a fundamental value by the users. In addition to the aesthetic value, the placement of the buildings creates an opportunity for infrastructural development: basic public services (e.g., public toilets, restaurants) can be located in facilities that fit the atmosphere of the park. In summary, it can be stated that the past and contemporary landscape architectural principles and also the park use habits overlap to a large extent $[4,75,76]$, and thus the 200-year-old Városliget is 
able to accommodate contemporary needs without compromising the historical character (cf. [75]). This explains the results of Szilágyi's research [44], which concludes that the visitors of Liget do not require serious structural changes. But physical accessibility often requires physical interventions, which in the case of Liget are validated neither by the historic values nor by the users participating in preliminary surveys. Therefore, before entering the design phase of the project, more detailed explorations were needed for the description of the needs and use habits of PwD. This research was carried out via social consultations.

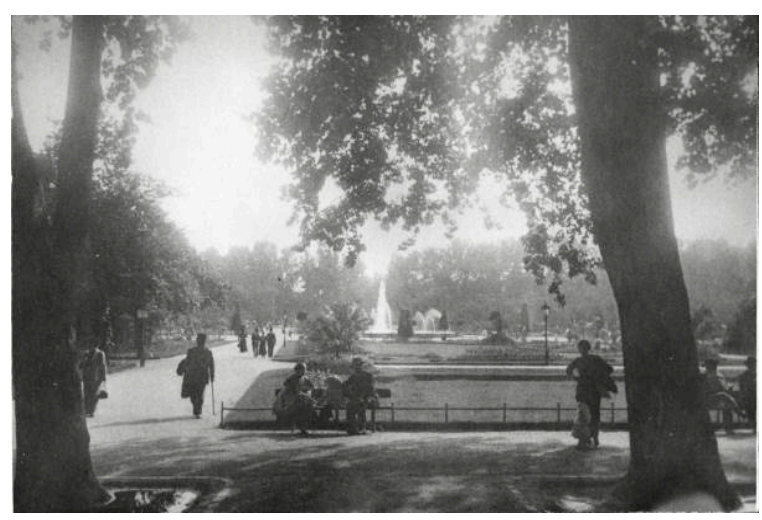

(a)

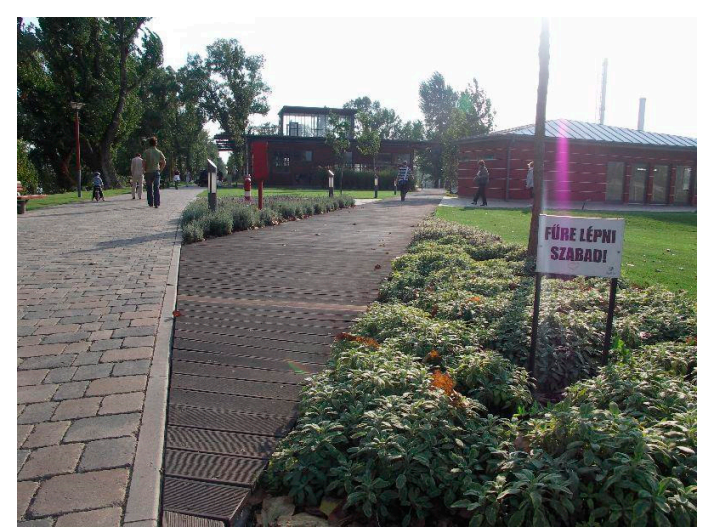

(b)

Figure 10. (a) Liget in former times, designer in English landscape style, mainly used as a place for passive leisure and for social contact. The small fence keeps visitors off the grass [72] (p. 45). (b) One of Budapest's large public parks: the Pro Architectura Prize awarded Kopaszi Dam in the Lágymányosi Danube Bay, designer: Garten Studio (also winner of the Liget design competition), year of award: 2009. In contemporary park usage, active recreation became also important beside passive leisure and social interactions. The board invites visitors to keep on the grass [77].

Based on the mentioned studies and researches on Liget's history and park usage patterns, in 2016 an international design competition was announced for the park rehabilitation of Városliget. The 1st prized Garten Studio [78] started the design phase with broad social consultations to gain more detailed knowledge about the general and special contemporary needs and park use patterns $[44,79,80]$. By comparing findings of the preliminary research and the social consultation, general and special needs and uses turned out to overlap greatly, which implicated that the park could be made accessible also to PwD with reasonable physical interventions.

The landscape design concept had to be prepared according to the Liget Accessibility Concept [81], whose principles were largely known and applied by accessibility professionals, and typically collects specifications for buildings. Although these strictly technical guidelines are nuanced by international examples of urban green spaces, the document itself does not use criteria specifically elaborated for a park with such a special historic and natural character. The requirements were consulted with the designer team and a broad range of stakeholders, but the main content did not change during the further development. Yet, the social consultations at the beginning of the design phase supported the use of UOSD's principles for a more inclusive result. The winner of the design competition cooperated with the relevant disability advocacies to complete recommendations for an inclusive Liget. Disability related advocacy institutions were invited to make comments, which were integrated to the project.

\subsubsection{The Preliminary Research and Design Process}

'Research for design': Literature review has been done continuously in the research topic. Related references are detailed in Section 2. 
'Research on design': The landscape conception plan of the Budapest city forest by Heinrich Nebbien, and the plans of the thematic Sensory garden from 1972 designed by Vera Csorba [72] were examined.

'Research about design': In relation to the project, site visits have been carried out since 2010 in an international European context to collect examples of different UD-related technical solutions on urban green spaces. (The thematic photo documentation about these site visits can be observed in Szaszák's PhD theses: Appendix MIII/2-Science photo library of Universal Open Space Design's international examples (cf. [41])).

In the context of the Liget design competition, Szaszák as a team member of Pagony Landscape Architects [82] conducted a survey on accessibility needs via the mailing list of the Hungarian Federation of the Blind and Partially Sighted (MVGYOSZ) (for more information about this forum see Section 4.1.2), reaching a significant number of people living with visual impairments. The comments from the mailing list of MVGYOSZ were included in the technical description of the design application of Pagony Landscape Architects [82] (Figure 11), and some of them later were incorporated into the Városliget park rehabilitation engineering program [83].

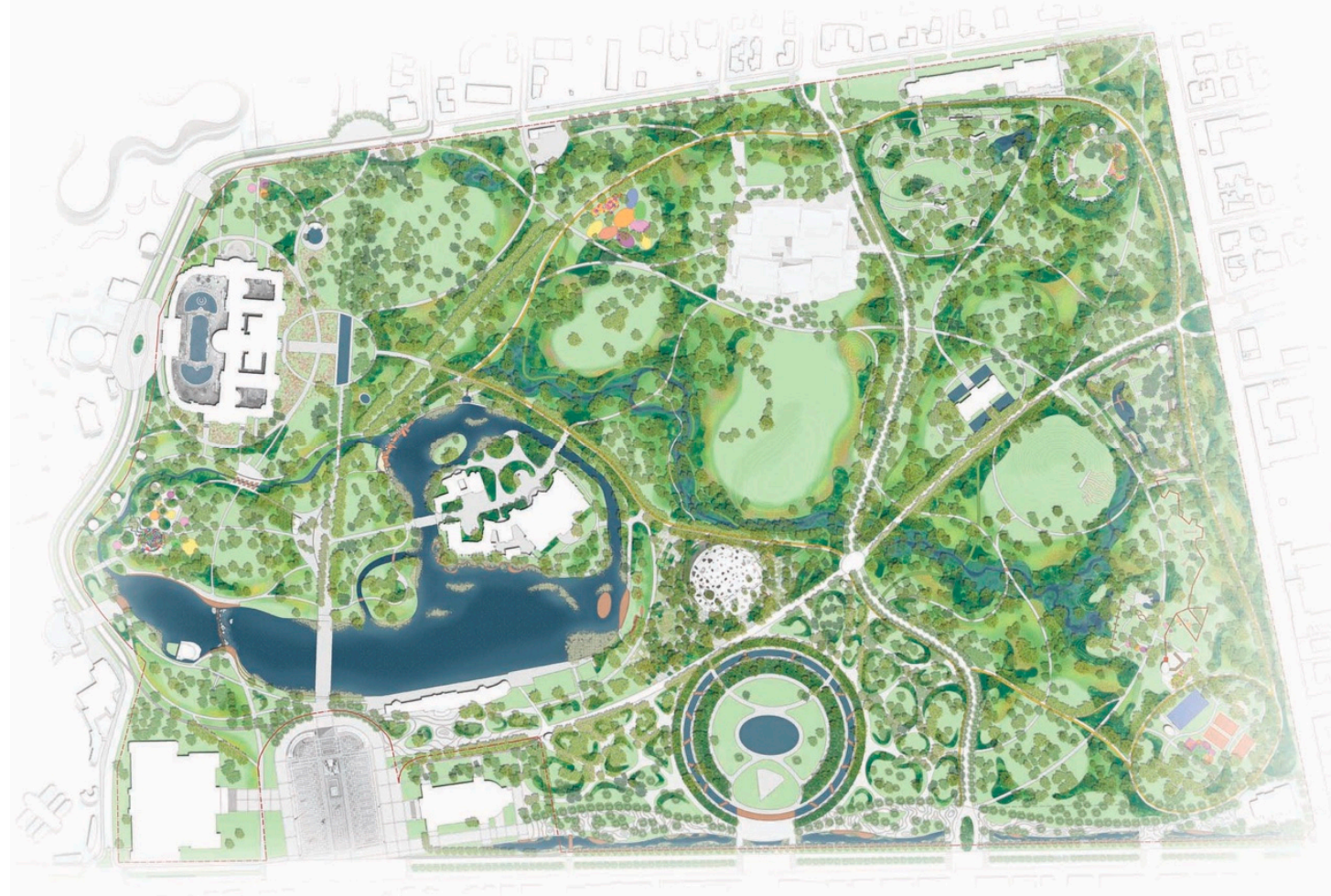

Figure 11. Liget design competition: landscape conception plan, designer: Pagony Landscape Architects, 2016; 3rd prize awarded [82].

\subsubsection{Research through Design}

As shown in Section 2.5, the primary service of urban green spaces is recreation and social life. The preliminary studies and surveys confirmed this thesis, as the main activities in the park were walking, social meetings and the use of institutional services. It was already stated that an open space is the public service itself, so equal access has to be provided to the largest extent reasonably possible (cf. Section 2.3). This statement is supported by a comment from the consultation forum for people living with reduced mobility and cognitive impairment. Question of the designer concerned the most important parts of the park which should be made accessible for PwD. The answer was that visitors with reduced mobility "use the entire area of the park. The equal access to each facilities 
and playgrounds is the most important, not so much their location" [80]. Consistency of the related strategies (historic park design, urban green space design, UOSD) was of high importance to sustain the historic character and provide equal access for all. The basic environmental components of UOSD completed with character-related aspects for urban public green spaces are summarized in Table A2.

According to the surveys, there was an explicit need for better walking surfaces. The interests of historic values and ecology raised the question of using stabilized pavements (cf. [81]), which can be of limited accessibility for people living with motor impairment (PwM). In the context of the social consultation, an interest in stabilized pavements occurred concerning their ability to meet the requirements for barrier-free use [80]. In Hungary, fine aggregate walking surfaces are usually not wheelchair-accessible. In Liget, properly compacted stabilized pavements were designed on the smaller paths. Stabilized aggregated pavements get depreciated faster than stabile pavements, so constant maintenance is required to keep their quality adequate.

Surveys also showed the explicit demand for more park furniture, meeting both the general and special user needs. Concerning colors and materials, the park's main value, that is naturalness had to be sustained in order to an enhanced nature experience. For the same reason, railings and bollards were used only at the edges and other intensive part of the park, where motorized traffic is present.

Wheelchair-accessible forms of stairs and ramps were planned in the environs of buildings. In the case of stairs integrated to paths with stabilized paving, the use of tactile signage is under consideration as the fine aggregates can spread to the stairs causing danger. It has been tested if the contrast of the different walking surfaces (stable stairs and stabilized aggregates) provided sufficient textural contrast for detectability.

One of the park's main values is old vegetation, which also provides protection from dust, noise, and aesthetic contamination. During the selection of the plants, the other main value, naturalness has been in the focus of the landscape architects.

Concerning orientation, it was emphasized by the organizations representing people with visual impairment $(\mathrm{PwV})$, that both the tactile walking surface indicators (TWSI) and the contrasting walking surface materials (CWSM) were valid in a green space to avoid the dominancy of artificial elements which can weaken the sense of nature. However, there is also a need for the TWSI system, especially along new, unknown routes, on the top landing of stairs, and on points where a danger (falling down, crossing of motorized traffic) is present. The Smart Liget application should also help achieve a more complex accessibility, but at the same time it is necessary to maintain the TWSI network so that it is not only possible to travel with a smartphone [79]. Further concerns about this subject are explained previously, at the description of stairs.

Direction signage and information about the available functions are of a high importance at a park's spatial scale. According to the advocacies of $\mathrm{PwV}$, fragrant plants and diverse vegetation are important elements of mood and orientation (and also ecology and sustainability), but there is no need for a tactile map outdoors [79]. The organization representing the interests of people with cognitive impairment emphasized the importance of Liget being easy to understand [80].

As a general requirement related to spatial functions, the composition of the special relations has to be designed carefully and sensitively in order to meet the needs of the park visitors. Adequate number of public toilets was highlighted by every invited stakeholder. Regarding the newly designed facilities (public toilets, catering units, other service buildings), all are expected to be barrier-free. The changing tables in wheelchair-accessible toilets are not supported, but family-friendly toilets are encouraged [80]. The design of public toilets should be uniform and visually impaired people should not be directed to accessible toilets [79].

The hierarchical system of promenades and paths provide exploration of the functions and attractions of the park. Based on the Accessibility Concept and the social consultations, three layers regarding their accessibility were separated:

- Promenades, squares, pavilions and their surroundings, thematic leisure areas providing basic public services and complex accessibility. 
- Units that evoke nature and are partially accessible, e.g., natural waterfalls.

- Areas that are not suitable for independent, barrier-free use, such as hills, large lawns, narrow paths [83].

When setting up the system, it was kept in mind that, within a regulated framework, as many experiences (landscape experiences) should be available to the visitors as they would otherwise encounter outside the built environment, in nature. When defining the individual sub-areas, the entire Liget was supposed to be as accessible as possible [83].

Pedestrian crossings and car parking places are parts of the urban fabric, and thus the requirements presented in the first case study should be applied. Within the Smart Liget program, Smart car parking platform has been elaborated, which will provide information about the free parking spaces and the route to them. The social consultants highlighted the importance of the public transport stops' equal accessibility and usability. The M1 underground, which was not built wheelchair-accessible, has to be renewed according to the principles of UD.

Concerning Liget's attractions, the accessibility of the lake and boating was also emphasized [80]. The design around the lake requires further negotiations, so that the safety of $\mathrm{PwV}$ and the organic, natural design that allows direct water contact with the lake can be realized at the same time [79]. Playgrounds, sports equipment, and sport facilities must be accessible to people with mobility impairments. There should be an aesthetic, transparent fence around the playgrounds and a luggage storage service should be available [80]. In terms of playgrounds, integrated design is important according to $\mathrm{PwV}$. The dog handler should have a fence, but can be shared as it is a place for social interactions [79].

During the park rehabilitation design process of Városliget, digital technology as a new planning tool has been involved. ICT tools called Smart Liget has been developed for improving visitor experience with the following planned platforms: websites, FB profile, Liget application, Liget newsletter, smart pay system, smart car parking, smart entrance control, Liget Wi-Fi hotspots, Liget smart spots, and digital signage spots. Frequently used services such as Google Maps, Waze or MOL Bubi public bike-sharing system can also be easily connected to the program. The free Wi-Fi network will be available in the entire area of the Liget. PwD using smartphones can connect to the system and receive special assistance when needed. Furthermore, audio maps GPS-based systems can help the orientation of $\mathrm{PwV}$. This is a priority, as they have several institutions and organizations around the Liget. With the help of smart devices, the web content developed for Liget will be virtually available everywhere in the Liget. In parallel, on the request of disability-related stakeholders, smart spot objects will be installed providing various services. $\mathrm{PwV}$ will be led with some kind of tactile signage to the smart spots. The theme has been developed by the smart Liget program. The object design of the smart spots will be elaborated with the involvement of an IT expert. The MVGYOSZ near the Liget has been testing other smart solutions which could complete the traditional assistive technologies, like the smart sensory tactile pavement with smart white cane wearable module [84].

\subsubsection{Significance and Uniqueness of the Project}

The preliminary phase of the design competition revealed that past and contemporary visitor's needs towards an urban park overlap to a large extent and thus only moderate physical interventions are necessary for the park rehabilitation. At the same time, physical accessibility often needs modifications. In Liget, it was shown, that general and special visitor's need also overlap greatly, and this way, based on a broad social digital communicative and personal consultation, equal access and use can be realized. The combination of top-down and bottom-up approaches was used for a more inclusive result. Disability-related professions were represented in the project from the beginning. In the design phase, social consultations confirmed that environmental components are inherent part of the open spaces' public services, and informed designers about its important consequences regarding partial accessibility. Referring to the Hungarian context (Section 2.4), this concept is widely applied and misunderstood. Designers often organize the public services into as few spatial units as possible in order to avoid 
accessible requirements on the possibly largest part of the certain space-mostly because of aesthetic considerations, but referring to undue financial burden or other external limitations. Understanding the importance of open spaces' public services can shift the core from "as few as possible" to "as many as possible" within the frames of the same concept, namely the partial accessibility.

Although the general requirements of the Liget Accessibility Concept were not sensitive to the special character of a park, the social participation ensured the realization of the UOSD principles. Also, the social consultation confirmed that the concept of 'partial accessibility' is valid only in parts which cannot be made accessible in a reasonable way, but the goal is to design the whole park as inclusive as possible. The widespread use of digital technologies is an important element of the project, although the platforms of Smart Liget concept are not yet green space specific, but follow the traditional structure of a general program developed for smart cities.

\subsection{Case Study for the Category "Semi-Natural Landscapes": The Accessible Nature Project}

\subsubsection{Context, Project Background and History}

The third case study presents accessible hiking trails and adventure sites planned along the former railway route in the Gerecse Landscape Protection Area and Natura 2000 Nature Reserve. The idea of an accessible campsite occurred, which could serve the hiking trail and provide a barrier-free recreational opportunity and natural places to special training for children living with disabilities. The idea came from a special educator, Béla Koczka, who contacted the Budapest Forestry Company to find the possibilities to realize the project.

The fenced garden of the Alsóvadács hunting lodge was designated to host the inclusive camping. The lodge's garden has a significant proportion of green space with native species, evergreen pines, and ornamental shrubs. There are typically no footpaths in the camp area, and the small paved surface is used for car traffic. There is an asphalt pavement at the main entrance and at the back entrance. The car park next to the building is equipped with a stabilized cover. The plot is typically used seasonally during winter hunts. The project promoted summer occupancy. The used structures had to be temporary, being able to be removed for the winter season. The campsite had to be designed suitable to accommodate barrier-free toilets, showers, and a dining area. Because of the interest of nature conservation, no trees were allowed to be fallen, thus the yurts had to be placed in clearings between the trees.

The Gábor Molnár nature trail was planned to start on the other side of the road bordering the plot. The the hiking trail is an abandoned railway track, thus providing a nearly level surface with an elevation of $0-3 \%$. The railway served the mining yards of three quarries along the first $1.5 \mathrm{~km}$ long section of the trail, which is also wide enough for forestry and service vehicles. The walking surface of this section is stable and largely smooth due to the former railway route and the occasional use of forestry vehicles. The mining yards of this area gave place to the disability-focused attractions of the trail (e.g., horse therapy, community play, educational events, and tourist attractions). At the time of the concept design phase (2012), no precedent for the project was available in Hungary, simultaneously having interest both in nature conservation and in physical accessibility in a natural forest. The project remained utopian so far, stopped at the concept design phase.

\subsubsection{The Preliminary Research and Design Process}

'Research for design': Literature review has been done continuously in the research topic. Related references are detailed in Section 2.

'Research on design': On-site landscape plans of the Skuleskogen and Söderasen National Parks (Sweden), and Katalinpuszta Visitors Centre (Hungary) were examined.

'Research about design': Lacking the Hungarian examples, experiences of international projects were examined and adapted. In relation to the project, site visits have been carried out since 2010 in an international European context to collect examples of different UD-related technical solutions on 
semi-natural landscapes. (The thematic photo documentation about these site visits can be observed in Szaszák's PhD theses: Appendix MIII/3-Science photo library of universal open space design's international examples (cf. [41])). The knowledge gained from site-visits is presented in the next chapter to be comparable with the two previous case studies.

\subsubsection{Research through Design}

Besides recreation, the special public services of landscapes with a natural character are visitation, education, and the presentment of natural values (cf. [85]). In near-natural areas accessibility regulations' application can be limited because of the primary interest of nature preservation and/or restoration. In order to achieve the proper result, interdisciplinary cooperation is needed between the related fields like ecology, nature conservation, landscape architecture, architecture, engineering, social sciences, legislation, etc. For the same reason, efforts should be made to ensure a balance of natural and artificial elements appropriate to the given environment when transforming an existing facility or creating a new one. If the nature conservation interest does not allow for (complex) accessibility, restrictions need to be introduced (e.g., fence, admission fee, limited opening hours, penalty, or even complete exclusion from the public). Universal landscape design offers many possibilities for access without endangering natural and cultural values, and even serving nature conservation interests. Natural elements cannot always be adapted to human needs and requirements, so physical accessibility is not always feasible. This is why it is important to learn about aspects of other professions to find alternative ways to provide accessibility while keeping the interests of conservation in mind. The principle of minimal intervention and adequate use of materials in natural areas is a priority and must be taken into account at all times-including when ensuring equal access. The basic environmental components of UOSD completed with character-related aspects for semi-natural landscapes are summarized in Table A3.

In the use of materials for ground surfaces, it is important to preserve the natural atmosphere in order to promote the natural experience. It is recommended to use natural, locally found materials (e.g., wood, stone, earth, peat) (Figure 12). Concrete or asphalt can be used on routes that are also suitable for motor vehicles. On other paths, unless a solid pavement is absolutely necessary, a stabilized scattered pavement with a natural appearance may be laid (coarse crushed stone is not suitable for the transport of rolling equipment). As this surface is water permeable, it fits into the natural environment both functionally and aesthetically and is widely used abroad (e.g., in Scandinavia) on barrier-free hiking trails. In the case of natural stone coverings, adequate evenness of the surface has to be provided. Wood cladding fits to the natural environment, but it is important to maintain its quality continuously. It can also be used to explore areas where the soil or vegetation cannot withstand trampling. The use of an artificial rubber cover is affordable where an obstacle-free shock-absorbing cover is required (other shock-absorbing covers are not wheelchair-accessible). Dirt roads, macadam, sand, and grass cover are allowed only when alternative access to the functions of the area is provided. During the construction work, the crop layer must be excavated and professionally deposited until the end of the construction, and then be spread again in the area when construction work is completed.

In the context of the accessible nature project, the primary considerations in choosing the pavements were simplicity and an aesthetic appearance that suited the natural environment. The new feature requires an increase in pedestrian traffic. In the garden of Alsóvadács, the terrain is slightly sloping, and the ground between the trees is uneven. The trees had to be protected, thus an elevated, modular, mobile wooden deck was designed to bridge the level differences, connected with wooden ramps to the ground (Figure 13). Trees required the use of water permeable stabilized pavements on the ground. This surface was also suitable to adjoin the ramps smoothly. The slope conditions of the mildly sloping area were adjusted only slightly, respecting the interest of nature conservation. Under the camp's wooden deck system, water drainage was proper into the natural soil. The green surfaces of the area absorbed the rainfall. 


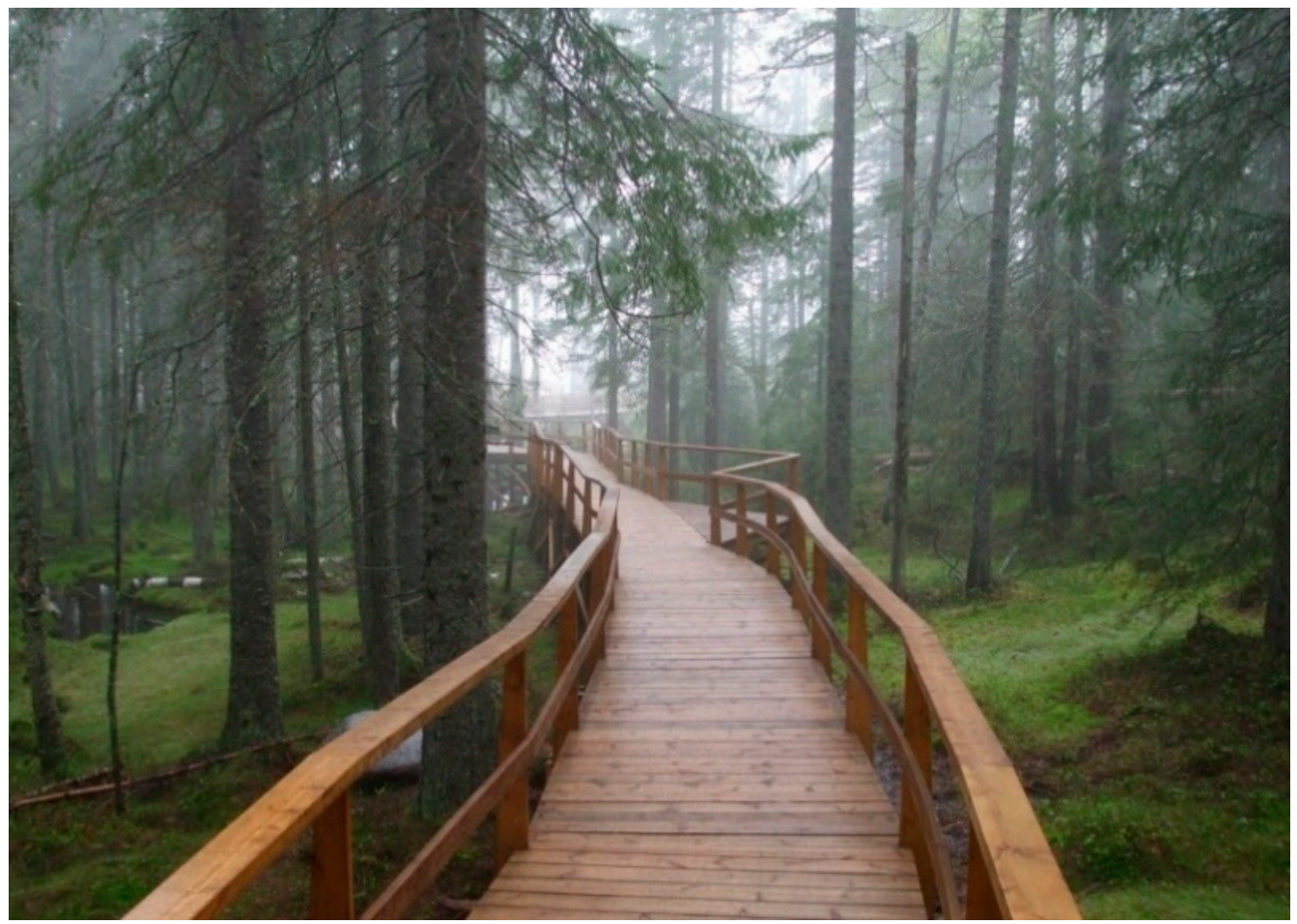

Figure 12. The wooden deck fits into nature while also protecting sensitive soil and vegetation sensible to treading, and allowing animals to cross underneath. The construction is designed to be wheelchair-accessible with wider tracks and meeting points. (Skuleskogen National Park, Sweden) [Source: Authors' own photo].

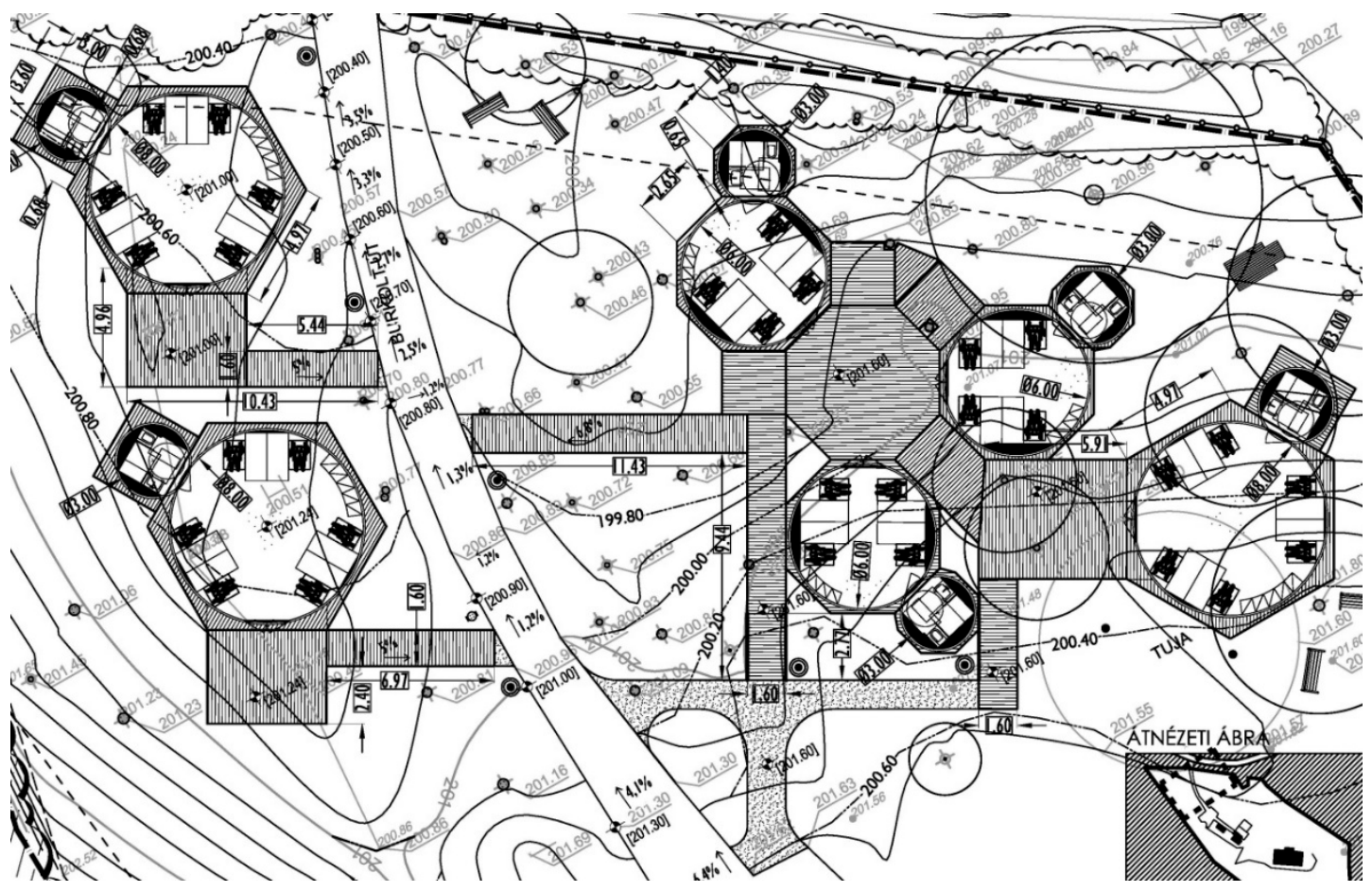

Figure 13. The camp site of Alsóvadács with mobile, wheelchair-accessible wooden ramps and decks between the existing trees. [Source: Authors' own design concept documentation]. 
The only planned intervention designed on the first, level part of the nature trail was to remove the stones from the traffic route and correct the unevenness and potholes, especially in the sections affected by the use of vehicles. If the use habits show that the walking surface was not wheelchair-accessible, it is necessary to design a pavement that can withstand the load of the vehicle, but also meets ecological, economic and usage criteria. On the further parts of the trail, elevation limits the usability for PwM, but the elimination of surface irregularities was recommended.

Concerning park furniture, natural materials were used to sustain the natural atmosphere. Product design was made for the bridging structure of the modular wooden decks, provided with accessible wooden handrails and ramps. The camp's seasonal yurt tents were located on this wooden deck system. Tasks and costs of the maintenance works received special attention already in the design phase, as local, natural materials need continuous preservation.

On the camp site, vegetation was not replaced by original species of the certain site on the owner's request. As on the nature trail there was room for educational, demonstrational, and recreational purposes, the restoration of biodiversity, which enhances the experience of nature, was planned.

As artificial contrast cannot be supported in a natural setting, the orientation was helped by a mild contrast from different textures found locally (for an international example see Figure 14a). Road curbs can help to find the way for visitors living with visual impairment. A continuous border helps keep direction, curves indicate connecting routes, breaking an edge can indicate targets, and contrast is important in orientation. Borders are also important when making audio maps. In the case of wider footpaths, the curb can serve as a wheelbarrow (Figure 14b), but can also be an obstacle if the ground would otherwise be suitable for receiving rolling equipment. On the Molnár nature trail, the stones to be removed from the road were planned to function as a road curb for PwV.

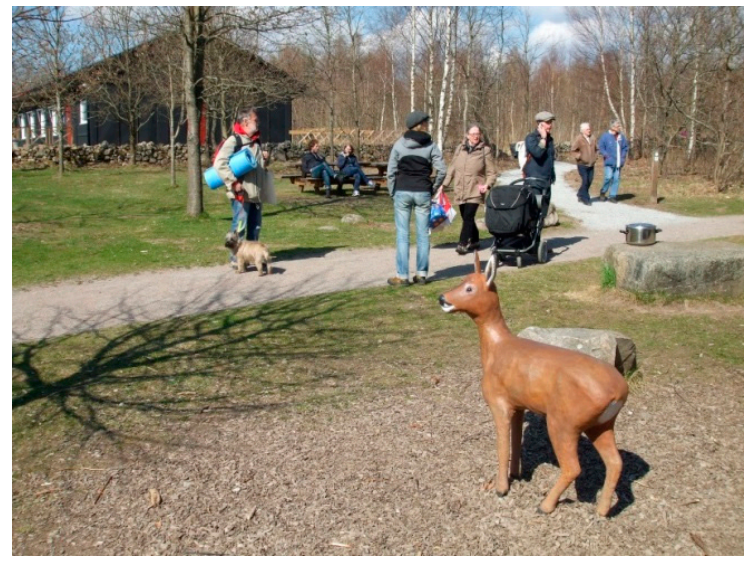

(a)

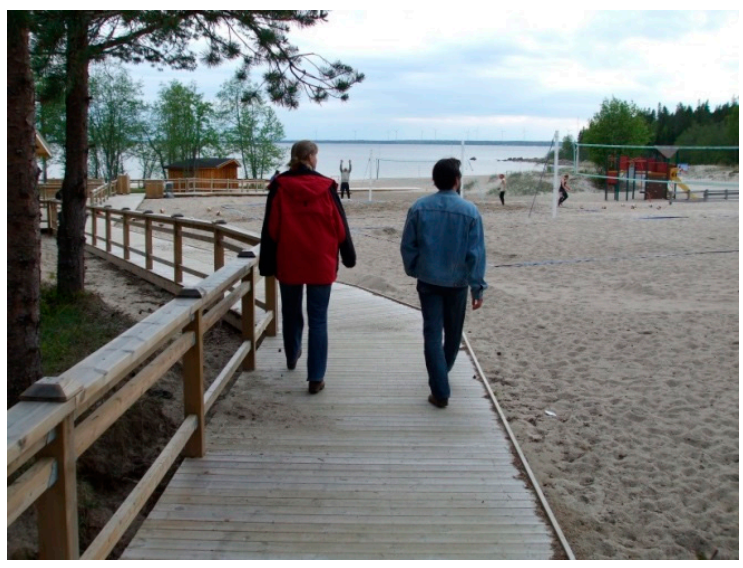

(b)

Figure 14. (a) Local materials and vegetation give a mild contrast which helps orientation and fits to the landscape (Skrylle Nature Reserve, Södra Sandby, Sweden) [Source: Authors' own photo]. (b) Wooden constructions with curbs can help orientation and serve as a wheelbarrow, when the original ground is not accessible by rolling equipment. (Umea, Sweden). [Source: Authors' own photo].

As this type of open spaces is large scale, an accurate information system was designed to be set up at intersections and junctions. Several signs were placed according to the needs of each user group. A well-designed signaling system was also important at entrances and at the start of roads. Different graphic features for different modes of transport (e.g., pedestrian, bicycle, horse, car, rail) were recommended, according to different detection distances. Way finding signage, information signs, landmarks, tactile guidance and orientation systems, lighting was intended to be completed with digital technologies supporting navigation, orientation, and info-communication (e.g., GPS navigation, audio maps, location-related applications). 
In semi-natural areas open to the public, it is recommended to have one or more barrier-free toilets at the entrance (barrier-free car park) and/or barrier-free destinations, depending on the size and functions of the area, unless this is contrary to the nature conservation interest. In the accessible nature project, the toilet was placed in an existing, unused building on the camping site. The use of a mobile toilet on the first, accessible part of the nature trail occurred, but was not realized so far. Buildings and edifices located in semi-natural areas must meet the ergonomic requirements for barrier-free use. In many cases, national park exhibition centers, ecotourism destinations, nature conservation museums and educational trails display some kind of nature conservation exhibition presenting the natural and cultural values of the area, even if the site itself cannot be accessed by all. Integrated, interactive smart exhibitions supplemented with digital technologies can also interpret the values of the area to people with disabilities. The barrier-free design of buildings located in natural areas (e.g., presentment and excursion centers, forest schools) is an easier task, especially if the existing building does not have to be adapted afterwards. These buildings are often located on the edge of the area to be presented, so the natural experience can be enhanced even when only the buildings are accessible for PwD.

In a natural environment, nature is revealed from the road network, thus it is especially important to design according to ecological principles. The roads connect and explore the area's natural values, attractions, and other objects perceptible through senses other than sight. The multiple, simultaneous sensation contributes to a reach landscape experience while moving in the space (e.g., touching cold-surfaced, rigid rock, trees of different trunks, flowers, berries and other wild fruits, streams, lakes). Areas with rich, protected wildlife should not be explored by roads, but, if the presentation is otherwise permissible and properly controlled, the road should pass by the protected area or avoid it in the case of a high degree of protection due to the vulnerability of the area. It is important not to fragment habitats when designing roads. The paths should be easily connected to the targets. The line drawing should be winding because it provides a natural effect.

In the case of a sloping area, there should be a route that follows the contour lines in order to avoid stairs, which also makes drainage and maintenance easier. Areas with slight slopes (e.g., stream valleys, lake shores, abandoned railway tracks, certain forest roads) can be made accessible for transporting rolling equipment (e.g., wheelchairs, bicycles, prams) with minimal interventions. In the case of educational, demonstrational, and recreational purposes, the experience of nature can be enhanced by developing the road network for example by widening paths. On narrow sections or sloping terrain, bypass points have to be installed (cf. Figure 12). If possible, closed loops of different lengths should be created. Routes with different levels of difficulty may have different surface, width, slope, length, edges, and rest places (Figure 15). At a minimum, an easy route should be available, depending on needs and terrain. For low-difficulty routes, as well as for larger level differences, it is recommended to install a (landscape-friendly) guardrail.

Natural areas open to the public should, as far as possible, be accessible by public transport and car (e.g., special taxis). Accessible destinations have to be reachable from the barrier-free car park on an accessible route. The car park should be located at the entrance, but if possible, the natural landscape should be revealed and dominate the view. In our project, car parking was located in the camp site for guests, and along the asphalt road adjoining the entrances of the camping and the tral for visitors.

Attractions-e.g., picnic, barbecue and campfire sites, lookout points, bird watching, waterfront fishing and bathing, study trails—should be preferably wheelchair accessible, which is more comfortable and safer for others. Lookouts are usually located at high altitudes, often even in relation to their surroundings, but by taking advantage of the terrain, wheelchair-accessibility can be provided (Figure 16). On the shores, the water can be accessible to PwM by ramp systems. 


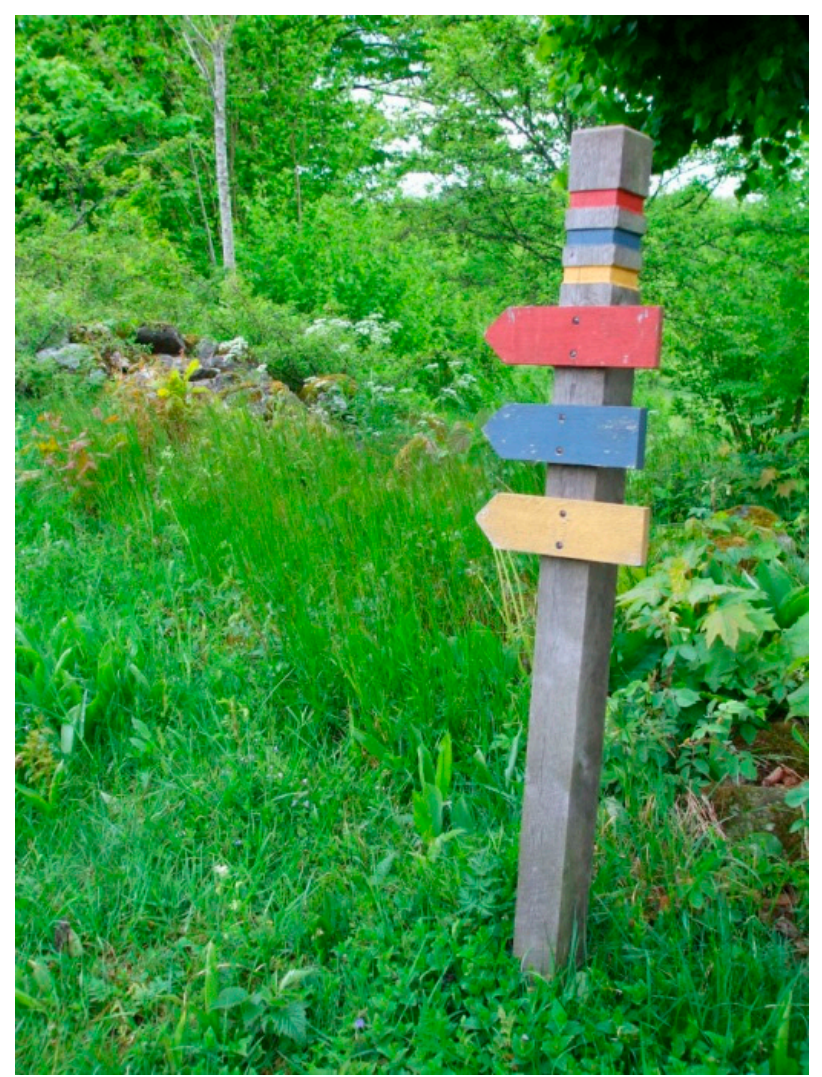

Figure 15. Different levels of difficulty and wheelchair-accessible routes can be signed with color codes, and even also symbols at the same time. Information should be placed at every crossings and junctions (Råshult, Sweden) [Source: Authors' own photo].

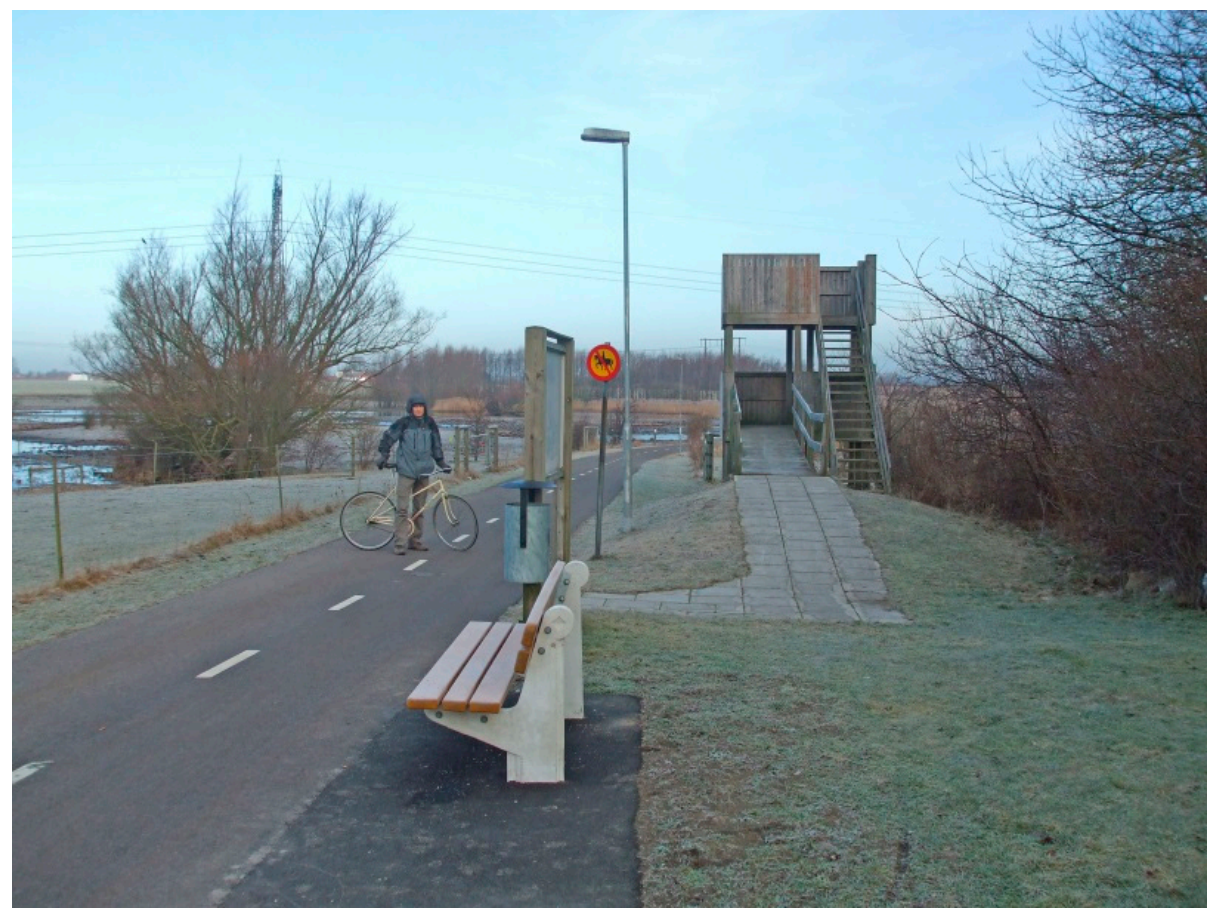

Figure 16. Smart use of terrain conditions provides access to bird watching and outlook points also for visitors using wheelchair. (Gullakra, Sweden) [Source: Authors' own photo]. 


\subsubsection{Significance and Uniqueness of the Project}

The Accessible Nature Project was the first in Hungary designing an accommodation and an accessible nature trail specifically to children living with disabilities. Attractions along the nature trail were places for special training in a natural environment. The idea was a nonprofit initiative, but the original team (including the authors of this article) failed to realize the project due to the occurrence of business interest from the owner's side. Still the project became a semi-functional prototype of an inclusive semi-natural landscape through which many inspiring examples were examined and experimented during the design process. The project revealed that interests of nature conservation and disability-inclusive development are compatible to a large extent.

When a part of a site cannot be made accessible for all, smart technologies have the potential to help visitors experience the site via other channels like moving in the space. Design tools of spatial arrangement and a legible, consistent info-communication system using smart technologies can contribute to experience nature and serve the interest of nature conservation at the same time. At the visited sites, smart platforms provided information and communication, e.g., through multilingual websites, social media, applications, interactive exhibitions, study trails, and Wi-Fi hotspots at visitor centers [86-88].

\subsection{The Interrelation of UOSD and Digital Technologies}

This chapter presented design projects which were conducted according to the principles of UOSD, combined with related concepts relevant to the certain project. In the case of the downtown of Budapest (OS-1), UOSD was combined with the use of digital technologies. The Liget Budapest Project (OS-2) further applied design tools of heritage protection. The Accessible Nature Project (OS-3) was conducted according to specific landscape design aspects related to nature conservation, ecology, and special education. Using the RtD method, environmental components were categorized, and findings were detailed along the certain categories, presenting also the applied digital technologies. This chapter summarizes the ICT-aspects of the projects. Table 3 presents the used digital solutions associated to the relevant environmental component (item).

Table 3 shows that the use of digital technologies was moderate in the case of the Károly Boulevard (OS-1) constructed in 2010, because at that time the ICT solutions was introduced to Hungary not a long ago. The design phase of the Liget Project (OS-2) started in 2016, and construction works will be finished by 2023. ICT tools have been under continuous development in parallel with the design process, and the intensive-although not green space-specific-use of smart solutions can be observed [89]. Digital tools listed at the Accessible Nature Project are international examples from Western- and Northern-European countries, which were ahead in the use of digital technologies.

The examined case studies were selected according the typology of open spaces based on their tolerance towards interventions. The results show that each environmental component can be linked to each public service of the open spaces (Table A4). Transport implies requirements towards the artificial elements, namely pavements, furniture, and bridging structures. Vegetation is considered as a physical factor which can influence the free moving in the space. Functional units for transport are the streets, squares, pedestrian crossings, and the modality changing points of car parking places and stops of the public transportation. Recreation involves also environmental objects and features ensuring info-communication. Vegetation counts as an ecological factor. Concerning spatial functions, the arrangement and the signage of each unit is relevant, and new elements like the play and sport facilities, and natural attractions appear. Where human activity is limited due to ecological interest, recreation is completed with learning, in order to educate the visitors on the protection of the natural values. In the accessible parts, spatial composition with aesthetic qualities is of higher importance to be able to provide the essence of the certain spots' atmosphere for a better nature experience. Inclusive socio-cultural life contains all three components of a landscape or cityscape: 'people', 'places', and 'technology', and these can be related to all types of open spaces. 
Table 3. Digital technologies applied in the design projects (case studies), categorized by the relevant environmental components (items). Foreign examples collected for the design process but not been realized are shown in italics.

\begin{tabular}{|c|c|c|c|c|}
\hline & Item & Public Urban Open Space (OS-1) & Public Urban Green Space (OS-2) & Semi-Natural Landscape (OS-3) \\
\hline 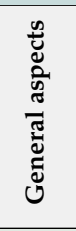 & universal access to public services & Completing strategies with ICT tools & $\begin{array}{c}\text { Completing strategies with ICT tools and aspects } \\
\text { of value protection; } \\
\text { Smart Liget platforms: websites, social media, } \\
\text { Liget application, Liget newsletter, Smart pay } \\
\text { system, Smart car parking, Smart entrance control, } \\
\text { Liget Wi-Fi hotspots, Liget Smart spots and Digital } \\
\text { Signage spots) }\end{array}$ & $\begin{array}{c}\text { Completing strategies with ICT tools and } \\
\text { ecological aspects; } \\
\text { Complex Smart Program: websites, social media, } \\
\text { application, interactive exhibitions, Visitor center Wi-Fi } \\
\text { hotspot, geocaching, Smart stops }\end{array}$ \\
\hline 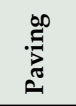 & surface, material, drainage & (TWSI at "orientation" below—audio map) & $\begin{array}{l}\text { Curbs and CWSM completing tactile } \\
\text { signage - audio map }\end{array}$ & Curbs replacing tactile signage—audio map \\
\hline$\stackrel{巳}{\stackrel{\Xi}{\Xi}}$ & type, surface, material, ergonomics & & Smart furniture (solar bench), Digital Signage spots & Interactive information boards on study trails \\
\hline \multirow{4}{*}{ 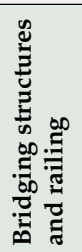 } & stairs & $\begin{array}{c}\text { Signed with TWSI (TWSI at "orientation" } \\
\text { below_audio map) }\end{array}$ & \multirow{4}{*}{$\begin{array}{l}\text { GPS navigation, } \\
\text { Liget application }\end{array}$} & \multirow{4}{*}{$\begin{array}{l}\text { GPS navigation, audio map, } \\
\text { location-related applications }\end{array}$} \\
\hline & $\begin{array}{l}\text { ramp, slope } \\
\text { handrail }\end{array}$ & & & \\
\hline & & & & \\
\hline & bridge, deck & & & \\
\hline
\end{tabular}


Table 3. Cont

\begin{tabular}{|c|c|c|c|c|}
\hline & Item & Public Urban Open Space (OS-1) & Public Urban Green Space (OS-2) & Semi-Natural Landscape (OS-3) \\
\hline$\frac{\infty}{\frac{\pi}{\pi}}$ & vegetation, plants & & BP Fatár application (tree cadaster) & website, GPS navigation + tag + application \\
\hline \multirow{5}{*}{ 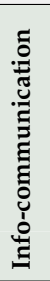 } & orientation: contrast, TWSI & Audio map & $\begin{array}{l}\text { Smart sensory tactile pavement with Smart white } \\
\text { cane, audio map }\end{array}$ & \\
\hline & navigation: direction signage & & $\begin{array}{l}\text { GPS navigation, } \\
\text { Liget application }\end{array}$ & GPS navigation, audio map \\
\hline & information: maps, functions & & $\begin{array}{c}\text { GPS navigation, Liget application, Smart spots, } \\
\text { Digital Signage spots }\end{array}$ & $\begin{array}{l}\text { GPS navigation, audio map, interactive tagged } \\
\text { information boards }\end{array}$ \\
\hline & communica-tion: audible support & Audible traffic signals at pedestrian crossings & Liget application & \\
\hline & lighting & Smart lighting (reduced during the night) & Smart Liget for sustainability & Smart lighting (according to ecological interest) \\
\hline \multirow{7}{*}{ 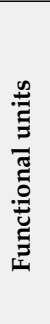 } & approaching, network, buildings & TWSI to toilets-audio map & Smart Liget & Complex Smart Program/Interactive exhibition \\
\hline & street, square & Audio map & Smart Liget & Complex Smart Program \\
\hline & pedestrian crossing & Audible traffic signals + mobile universal device & Smart Liget & Complex Smart Program \\
\hline & car parking & & Smart Liget/Smart car parking & Complex Smart Program \\
\hline & stop of public transport & $\begin{array}{c}\text { Smart stops, electronic timetable, route info } \\
\text { combined with mobility vehicles, application } \\
\text { (BKK Futár), Audible traffic information with } \\
\text { mobile universal device }\end{array}$ & $\begin{array}{c}\text { Smart stops, electronic timetable, route info } \\
\text { combined with mobility vehicles, application (BKK } \\
\text { Futár), Audible traffic information + mobile } \\
\text { universal device }\end{array}$ & Complex Smart Program \\
\hline & play \& sport facilities & & Smart Liget & Complex Smart Program \\
\hline & natural attractions & & Smart Liget & Complex Smart Program/Interactive study trails \\
\hline
\end{tabular}


The environmental components-objects, features, and spatial units-are inherent part of the open spaces' public services. Concerning the user experience (cf. Figure 1: spatial Maslow pyramid/environment/supportivity to users), keywords of the related design strategies hierarchized after the level of inclusion (Figure 17: digital Maslow pyramid/spatial design) can be associated with the certain environmental components, and therefore also with the public services. This way, a hierarchy of the public services can be suggested. In this context, transport can be related to the basic level of the spatial Maslow pyramid, where 'physical' accessibility must be realized (Figure 17). In the case studies, recreation is most related to green spaces with less modifiable natural components. Inaccessible parts of a certain open space can be separated, but appropriate adjustments must be applied. So, urban green spaces can be made accessible to some extent even in the case of partial physical accessibility, so that people are not totally excluded from its use. Therefore, the primary service of recreation can be associated with the 'sensual' second level of the spatial Maslow pyramid. Where natural elements are dominant and nature conservation limits the possibility of physical interventions, beside recreation, learning also becomes important. This service is not basic for physical or sensory accessibility, but contributes to the improvement of each individual's experience of space and nature, representing 'aesthetic' value. The 'social' top level of the spatial Maslow pyramid can be associated with socio-cultural experience, which is the result of the inclusive use of all public services in an open space designed after the principles of UOSD combined with ICT.

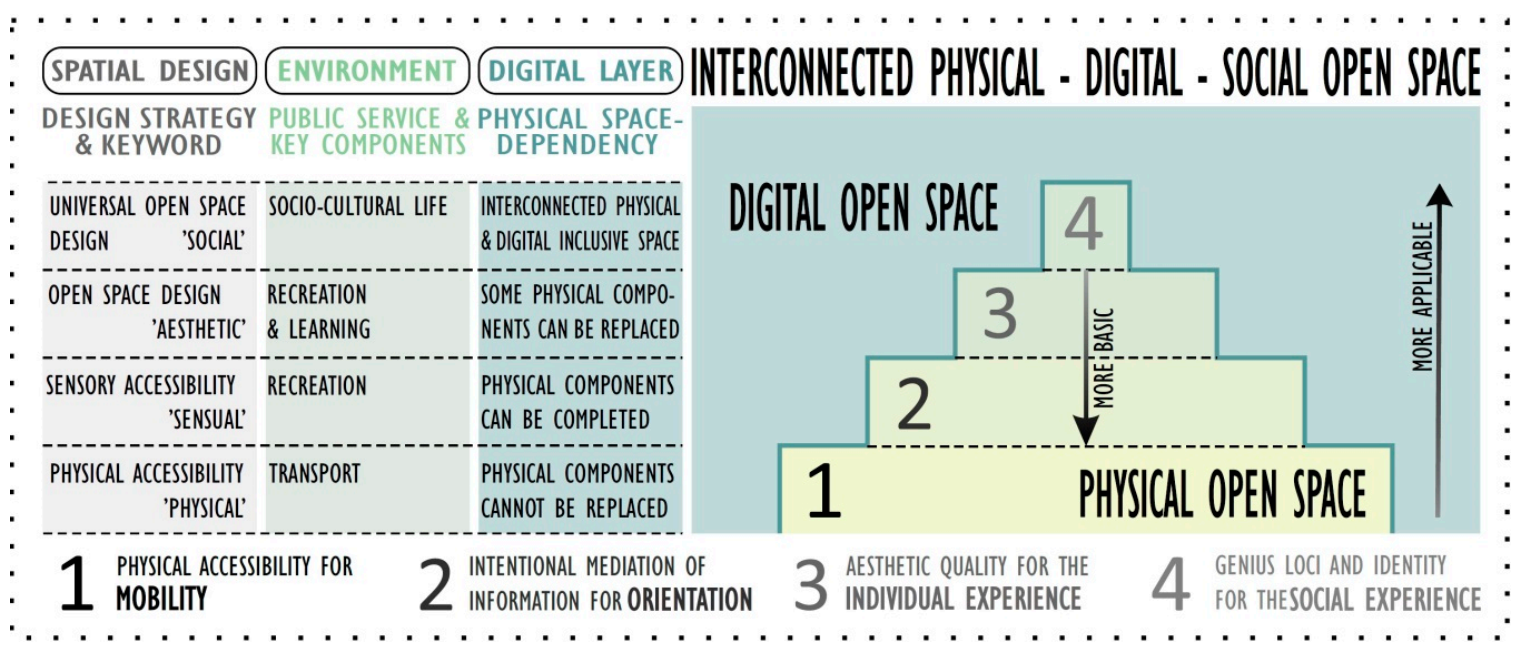

Figure 17. The "digital" Maslow pyramid of user needs related to the relevant spatial design concepts, the open spaces' public services and the digital technologies.

It must be noted, that the digital Maslow pyramid is a model. Its levels are in strong interrelation, as each situation is unique, and public services are present in combinations. Therefore, an own inner hierarchy of each public service-related to the design project and their prioritized design strategies-can also be observed.

As transport is essential to the functioning of the city, the basic spatial level is the most dominant in its inner hierarchy. Environmental components related to transport must meet the strictest accessibility requirements. This means that all elements of the physical space must be accessible, usable, or avoidable so that everyone can use its service on an equal basis. If certain elements such as barriers are present, some people may be excluded from the use of the open space, i.e., the public service. At the same time, as transport's environmental components are dominantly artificial, they are the most compatible with the requirements of physical accessibility, and among the spatial elements, those related to transport are the most barrier-free in our open spaces. As these components have to meet physical accessibility requirements, cannot be replaced by digital technologies, but can provide a basis for ICTs' digital layers to enhance inclusive environmental engagement. For example, GPS navigation can 
support walking and multimodal mobility by calculating the route along the relevant parameters (e.g., avoidance of stairs or narrow and sloping walkways, or the use of a public service). By selecting the parameters according to their needs, users will be able to choose the most suitable route. (The different accessibility needs related to the hierarchic levels of the Maslow pyramid of user needs are shown in Table 1, Section 2.3). In the digital Maslow pyramid (Figure 17), the second level is associated with sensory accessibility, where the existence of info-communication supportive components contributes largely to the independent and safe use of the open spaces. Moving upwards, the requirements are becoming less exclusive, but still need to be physically barrier-free, or provide alternative (physical) routes. Thus, proper spatial arrangement is of high importance. Environmental elements on the second level can be complemented with digital technologies for the increase of autonomy and safety. For example, TWSI, CWSM, and contrasting landmarks completed with GPS navigation or audio maps provide enhanced accessibility for PwV. On the third level, for enhancing aesthetic experience, transport requires a deliberate spatial composition of environmental elements which explore the area's values. The top level implies a continuous travel chain completed with a continuous information chain for an inclusive smart transport.

While the spatial Maslow pyramid's levels are more basic downwards, digital technologies do not have a hierarchy in the opposite direction, but are freely interconnected to spatial elements and are more widely applicable upwards. Therefore, concerning public services other than transport (which requires basic spatial conditions), which are associated with the higher, less basic levels of the spatial Maslow pyramid, similar consequences regarding the relevant environmental elements can be described (cf. Table A4). The public services (e.g., sport, play, social life) of the units that cannot be made fully accessible, may be relocated to another spot within the area. In this case, the reorganization of the service has to provide as broad participation as possible, according to reasonable accommodation (cf. social consultation about Liget, OS-2 case study). These consequences are even more valid when moving upward along the hierarchy of spatial needs. Physical accessibility should not be strictly accounted for, but rather provided to the extent possible and reasonable, and the values of areas that cannot be made physically accessible should be complemented or replaced by additional digital information. Where physical modification is limited or impossible, design tools completing-and not transforming - existing features have the potential to make the certain site more accessible. Such tools are careful spatial composition and info-communication using smart technologies. For example, interactive exhibitions and tagged study trails can educate visitors; GIS geocaching gives the playful experience of nature; nature related applications can share knowledge. In the case of an inclusive network of open spaces, a complex sociocultural experience can be achieved. Digital services at this level can facilitate for example data collection and direct data feedback, sharing knowledge, participatory platforms, personalizing spaces, place-making, or engagement with locations (cf. [15]). The continuity is important in order to be able to choose from alternatives suitable for each individual, and this way the effect of inaccessible units or services of open spaces can be reduced and compensated. Digital technologies of the upper level are the most space-independent. In such a network, public services are interconnected spatially, socially, and digitally, augmenting disability-inclusion.

In summary, the type of the open space influences the environmental components relevant to accessibility and usability, because each type can be characterized by a primary public service, and spatial elements can be related to public services, which were associated with each level of the spatial Maslow pyramid (cf. Figure 1 in Section 2.3 and Table A1 referred in Section 2.1). Thus, the type of open space influences the primary public service, which in turn determines the expected level of inclusion.

\section{Discussion}

Basic components of the city, namely 'people' and 'place' were examined to inform 'technology' about the possibilities of a digitally augmented inclusion of the open spaces. User needs, environmental components and relevant design concepts were hierarchized and linked to open spaces' public services. 
The basic role of these public services in spatial inclusion, and the relevancy of their environmental components were outlined, and categorized into three digitally related types: non-replaceable components must meet physical accessibility requirements, and two more groups are formed the digitally replaceable components, and those that can or need to be complemented.

The three presented case studies revealed the dominancy of 'transport' among the open spaces' public services, which is highly connected to the physical environment. It is linked to artificial environmental components, which are the easiest to be made physically accessible, have to be made physically accessible, and are already the most physically accessible according to the case studies and site visits. These components cannot be replaced by digital technologies. Other public services (e.g., recreation, learning, sociocultural life) are more place-independent and often must meet other relevant concept which influence the degree of physical accessibility (e.g., heritage protection or nature conservation). This means that the disability-sensitive reorganization of the spatial units and their public services is affordable according to the reasonable accommodation, which ensures that people have inclusive access to as much space as possible. The environmental components of these public services can and need to be complemented, or even replaced by digital layers, so ICTs are the most applicable to them.

Referring to the cited literature and the case studies, the dominancy of transport and physical accessibility regarding open spaces can be observed also in the use of smart strategies and tools. This study revealed that upper (less basic) levels of the spatial and digital Maslow pyramid related to public services other than transport and concepts other than physical accessibility lack digital completion or replacement, although these digital layers would be basic for people's inclusion and for the places' inclusivity, protection and inviting layout. For example, ICTs attached to the environmental elements, which are relevant for sensory accessibility (e.g., TWSI, CWSM, landmarks), would significantly improve the safety and independency of people living with sensory disabilities. This is more basic than support a more convenient transit in the physically accessible environment, i.e., apply ICT tools with transport related to physical accessibility in focus. Digital technologies can enrich and augment the individual and social experience of open spaces.

Concerning strategies related to open space design, the extensive overlap of the concepts' principles; the contemporary and past use patterns; and the general and special user needs was discovered, which means that traditional open space design covers a significant part of UOSD. This way, design projects tend to contribute to a more inclusive environment even when UOSD principles are not followed. At the same time, it was confirmed that UOSD principles implying ICTs are more effective and sustainable when applied from the beginning of the design process.

It can be seen, that the focus of the referred studies in the subject of smart technologies is based on ICTs and user needs (i.e., people and technology), and explore what opportunities ICTs provide to better understand the user needs and use patterns in order to interrelate with the space (place). Our research started from people and place and examined which components the technology can supplement or replace. The hierarchies of the digital Maslow pyramid inform ICTs about their role and significance in enhancing spatial and social inclusion. In this context, results point out that digital technologies are the most applicable and needed on the upper levels of the spatial hierarchy of accessibility needs, which can be also sorted by the different disabilities. Thus, digital layers can be purposefully developed, knowing what the relevant spatial components are which can be used as channels or subjects of info-communication.

The simplification of reality for creating the used models can be a limitation factor to this study. UOSD is a complex concept, each situation is unique and face its own challenges bringing in other, contrary aspects, and the extent of reasonable accommodation is also hard to be determined. However, the results provide a good starting point for disability-inclusive projects, and a guideline for the social participation and the design process. Furthermore, user needs and usage patterns of $\mathrm{PwV}$ are less known and understood, and therefore the design projects became real scaled experiments in the city, 
which induces aesthetic concerns regarding urban spaces, influencing the spatial experience of the average user. Participation of PwD in the design process is therefore crucial.

Suggestion for future research is to reveal more space-connected digital tools for open spaces' public services other than transport in order to support place-making and strengthen identity. Moreover, the more detailed research into the disability-focused interrelation of 'people' and 'place' can involve new technologies, enriching the practical background of the subject. Furthermore, results of this research were based on related international literature and Hungarian design projects. The exploration of international examples could help to compare the context of Hungary to other contexts, add details to the research, generating important theoretical and practical knowledge. Concerning diverse user needs, the attitude of the youth and the elderly population towards digital technologies is also special. The scientific observation of good practices can provide generalized lessons to augment this research with relevant details.

\section{Conclusions}

This research explored the city's open spaces through the detailed analysis of its two components, viz. people and place, in order to inform its third component, technology for an augmented disability-inclusion. People's user needs and usage patterns; open space's environmental components (spatial objects, features and units) and types (according to their tolerance towards physical modification); and relevant disability-related concepts linked to UOSD were hierarchized and interrelated to open spaces' public services and the digital layers that can replace or complement the environmental components. The research outlined that access to these public services is basic in spatial inclusion. Environmental components themselves are immanent parts of the open spaces' public services. Therefore, their relevancy and character were explored, and the "digital" Maslow pyramid of user needs related to the relevant spatial design concepts, the open spaces' public services and the digital technologies was elaborated. As a result, three main categories of environmental components were defined: (1) components that must be made physically accessible and cannot be replaced by digital technologies; (2) components that can be complemented; and (3) components that should be replaced because of their incompatibility of the physical accessibility requirements.

Through three Hungarian design projects, the dominancy of 'transport' among the open spaces' public services was revealed. As this service has strong physical relations and is basic in the operation of the city, it stands in the focus of UOSD and ICT strategies. Although physical accessibility associated with 'transport' is the most basic level of the spatial Maslow pyramid, ICTs are more applicable in relation to other design concepts (e.g., sensory accessibility, UOSD) and public services provided by open spaces (e.g., recreation, learning, sociocultural life). These services require careful design of spatial composition and disability-inclusive organization rather than physical accessibility, according to the principles of UOSD.

The spatial basis of 'transport'-related physical accessibility cannot be replaced by digital technologies, but a barrier-free environment can serve as a basis for digital layers supplementing physical components (e.g., TWSI, CWSM, landmarks), providing sensory accessibility, which is basic for PwV. In the case of incompatibility with the requirements of physical accessibility, environmental components can be complemented or replaced by ICT, following the principles of UOSD. The significant overlap of the general and special user needs, and the contemporary and past use patterns moves traditional design strategies in the direction of UOSD, as it enriches their common background. These phenomena shift the urban development towards a more disability-inclusive approach.

Other cited studies in the field of smart technologies used ICTs to understand user needs in order to improve their spatial performance and experience. Our research approached from a spatial point of view and ranked the physical components and public services of open spaces according to their type of digital applicability as a channel or subject for ICTs. In conclusion, this paper demonstrates how the combination of the tools of UOSD and ICTs support a more complex disability-inclusive experience in an interconnected physical, sociocultural, and digital network of open spaces. 
Author Contributions: All chapters of this article were written by both authors. All authors have read and agreed to the published version of the manuscript.

Funding: This research received no external funding.

Conflicts of Interest: The authors declare no conflict of interest.

\section{Appendix A}

Table A1. Basic accessibility needs of PwD concerning the external, environmental factors [16].

\begin{tabular}{|c|c|c|c|c|c|}
\hline \multirow[t]{2}{*}{ External Environmental Factor } & \multicolumn{5}{|c|}{ Impairment } \\
\hline & $\frac{0}{0}$ & 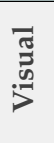 & 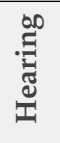 & $\overbrace{0}^{0}$ & $\frac{\overrightarrow{2}}{\frac{d}{2}}$ \\
\hline Clear pedestrian traffic gauge & $\checkmark$ & $\checkmark$ & & & \\
\hline - detection of hanging objects and protruding obstacles & & $\checkmark$ & & & \\
\hline Vertical dimensions, slopes & $\checkmark$ & & & & \\
\hline - stairs are difficult to use or unusable & $\checkmark$ & & & & \\
\hline - ramp inclination is limited & $\checkmark$ & & & & \\
\hline Clear space for maneuvering & $\checkmark$ & & & & \\
\hline Human dimensions, ergonomics & $\checkmark$ & $\checkmark$ & & & $\boldsymbol{V}$ \\
\hline - lower access zone & $\checkmark$ & & & & \\
\hline - lower eye height (as for children) & $\checkmark$ & & & & \\
\hline - transparent space $\rightarrow$ a sense of security & $\checkmark$ & & & & \\
\hline - clear space for the knee & $\checkmark$ & & & & \\
\hline - barrier-free walking surfaces & $\checkmark$ & $\checkmark$ & & & \\
\hline - even, level, stable, slip-resistant, non-reflective surfaces & $\checkmark$ & $\checkmark$ & & & $\checkmark$ \\
\hline Distances & $\checkmark$ & $\checkmark$ & & & $\checkmark$ \\
\hline - slower motion (e.g., at a pedestrian crossings) & $\checkmark$ & $\checkmark$ & & & $\checkmark$ \\
\hline Lighting & & $\checkmark$ & & & $\boldsymbol{V}$ \\
\hline - difficulty in tracking sharp changes in lighting & & $\checkmark$ & & & $\checkmark$ \\
\hline Contrast & & $\checkmark$ & $\checkmark$ & $\checkmark$ & $\checkmark$ \\
\hline - dangers (stairs, pedestrian crossings with curb ramps) & & $\checkmark$ & $\checkmark$ & $\checkmark$ & $\checkmark$ \\
\hline - destinations, attractions & & & $\checkmark$ & $\checkmark$ & $\checkmark$ \\
\hline Information via multiple channels & & $\checkmark$ & $\checkmark$ & $\checkmark$ & $\boldsymbol{V}$ \\
\hline - simultaneous tactile and audible information & & $\boldsymbol{V}$ & & & \\
\hline - visually displayed audible information (e.g., alarms) & & & $\boldsymbol{V}$ & & \\
\hline - moderate level of stimulus to avoid extreme reactions & & & & $\checkmark$ & \\
\hline Well-organized space composition & & & & $\checkmark$ & $\checkmark$ \\
\hline - well-structured spaces & & & & $\checkmark$ & $\boldsymbol{V}$ \\
\hline Diverse, not monotonous spaces & & & & & $\boldsymbol{V}$ \\
\hline - versatile, compact environment & & & & & $\checkmark$ \\
\hline - diverse urban and architectural exteriors & & & & & $\checkmark$ \\
\hline Spaces to emphasize and navigate & & $\checkmark$ & $\checkmark$ & $\checkmark$ & $\checkmark$ \\
\hline - indication of directions & & $\boldsymbol{v}$ & $\checkmark$ & $\checkmark$ & $\checkmark$ \\
\hline - well-recognizable landmarks & & $\checkmark$ & & $\checkmark$ & $\checkmark$ \\
\hline - practical and aesthetic environment & & & & & $\checkmark$ \\
\hline Spaces to connect and separate & & & & $\checkmark$ & \\
\hline - well-separable functional units & & & & $\checkmark$ & \\
\hline Legible, clear, understandable spaces & & $\checkmark$ & $\checkmark$ & $\checkmark$ & $\checkmark$ \\
\hline - consistent information signage system & & $\checkmark$ & $\checkmark$ & $\checkmark$ & \\
\hline - capital letters and pictograms & & $\boldsymbol{v}$ & $\checkmark$ & $\checkmark$ & \\
\hline - simple, concise, clear, consistent information & & $\checkmark$ & $\checkmark$ & $\checkmark$ & \\
\hline $\begin{array}{l}\text { - safe, predictable, accessible physical and social } \\
\text { environment }\end{array}$ & & & & $\checkmark$ & \\
\hline
\end{tabular}


Table A1. Cont.

\begin{tabular}{|c|c|c|c|c|c|}
\hline \multirow[t]{2}{*}{ External Environmental Factor } & \multicolumn{5}{|c|}{ Impairment } \\
\hline & $\frac{\text { t̆ }}{\text { ț }}$ & 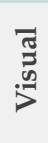 & 苞 & 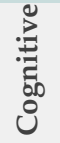 & $\frac{\lambda}{\frac{2}{0}}$ \\
\hline - functions of places, spaces and buildings are clear & & & & & $\checkmark$ \\
\hline - the location of the entrance or gate is clear & & & & & $\checkmark$ \\
\hline - simple, expressive signs with contrasting graphic & & & & & $\boldsymbol{V}$ \\
\hline Friendly, aesthetic spaces & & & & & $\boldsymbol{V}$ \\
\hline - short, gently curved, wide, clear, transparent footpaths & & & & & $\boldsymbol{V}$ \\
\hline $\begin{array}{l}\text { - calm pedestrian zones and inviting, welcoming open } \\
\text { spaces }\end{array}$ & & & & & $\checkmark$ \\
\hline $\begin{array}{l}\text { easy-to-use street furniture designed familiar to the } \\
\text { elderly }\end{array}$ & & & & & $\boldsymbol{V}$ \\
\hline
\end{tabular}

Table A2. Environmental components of UOSD in the focus of research and design, completed with character-related aspects for urban public green spaces (OS-2).

\begin{tabular}{lll}
\hline Category & Item & Character-Related Aspects (OS-2) \\
\hline General aspects & universal access to public services & harmony of related design principles \\
\hline Walking surface & surface, material, drainage & stabilized pavements \\
\hline Park furniture & $\begin{array}{l}\text { surface, material, ergonomics } \\
\text { car parking }\end{array}$ & naturalness, nature experience \\
\cline { 2 - 3 } $\begin{array}{l}\text { bench, table, drinking fountain, litter bin, } \\
\text { information board, pavilion, etc. }\end{array}$ & \\
\hline \multirow{2}{*}{$\begin{array}{l}\text { Bridging structures } \\
\text { and railing }\end{array}$} & stairs & considering the use of tactile signage \\
\cline { 2 - 3 } & ramp, slope & on accessible routes \\
\cline { 2 - 3 } & handrail, traffic-directing structures & on accessible routes \\
\hline Vegetation & plants & naturalness, nature experience \\
\hline \multirow{2}{*}{ Info-communication } & $\begin{array}{l}\text { orientation: contrast in light and color, } \\
\text { tactile signage }\end{array}$ & considering tactile and naturalness \\
\cline { 2 - 3 } & navigation: direction signage & important \\
\cline { 2 - 3 } & information: maps, functions & important \\
\cline { 2 - 3 } & communication: audible support & considering nature experience and ecology \\
\cline { 2 - 3 } & lighting & considering ecological interest \\
\hline \multirow{2}{*}{ Functional units } & approaching, network, buildings & on accessible routes \\
\cline { 2 - 3 } & streets, squares & hierarchy of pedestrian network \\
\cline { 2 - 3 } & pedestrian crossings & at intense, artificial parts \\
\cline { 2 - 3 } & car parking & at intense, artificial parts (edges) \\
\cline { 2 - 3 } & stops of public transportation & at intense, artificial parts (edges) \\
\cline { 2 - 3 } & playgrounds, sport facilities, dog handlers & new element \\
\cline { 2 - 3 } & attractions with natural character & new element \\
\hline & & \\
& & \\
& & \\
& &
\end{tabular}


Table A3. Environmental components of UOSD in the focus of research and design, completed with character-related aspects for semi-natural landscapes (OS-3).

\begin{tabular}{lll}
\hline Category & Item & Character-Related Aspects (OS-3) \\
\hline General aspects & universal access to public services & harmony of related design principles \\
\hline Walking surface & surface, material, drainage & stabilized pavements if possible \\
\hline Park furniture & surface, material, ergonomics & naturalness, nature experience \\
\cline { 2 - 3 } & $\begin{array}{l}\text { bench, table, drinking fountain, litter bin, } \\
\text { information board, pavilion, etc. }\end{array}$ & \\
\hline Bridging structures & stairs & at visitor's centers \\
\cline { 2 - 3 } and railing & ramp, slope & at visitor's centers \\
\cline { 2 - 3 } & handrail, traffic-directing structures & on designated accessible loops \\
\cline { 2 - 3 } & bridge, wooden path, wooden deck & new element \\
\hline Vegetation & plants & ecology, nature conservation \\
\hline Info-communication & orientation: contrast in light and color, tactile signage & at visitor's centers \\
\cline { 2 - 3 } & navigation: direction signage & important \\
\cline { 2 - 3 } & information: maps, functions & important \\
\cline { 2 - 3 } & communication: audible support & at visitor's centers \\
\cline { 2 - 3 } & lighting & on designated accessible loops \\
\hline Functional units & approaching, network, buildings & at visitor's centers \\
\cline { 2 - 3 } & streets, squares & loops of different difficulty \\
\cline { 2 - 3 } & pedestrian crossings & at the entrance, outside the site \\
\cline { 2 - 3 } & car parking & at the entrance, outside the site \\
\cline { 2 - 3 } & stops of public transportation & considering ecological interest \\
\cline { 2 - 3 } & playgrounds, sport facilities & considering ecological interest \\
\cline { 2 - 3 } & attractions with natural character & \\
\hline
\end{tabular}

Table A4. Environmental components linked to the main public services of the open spaces.

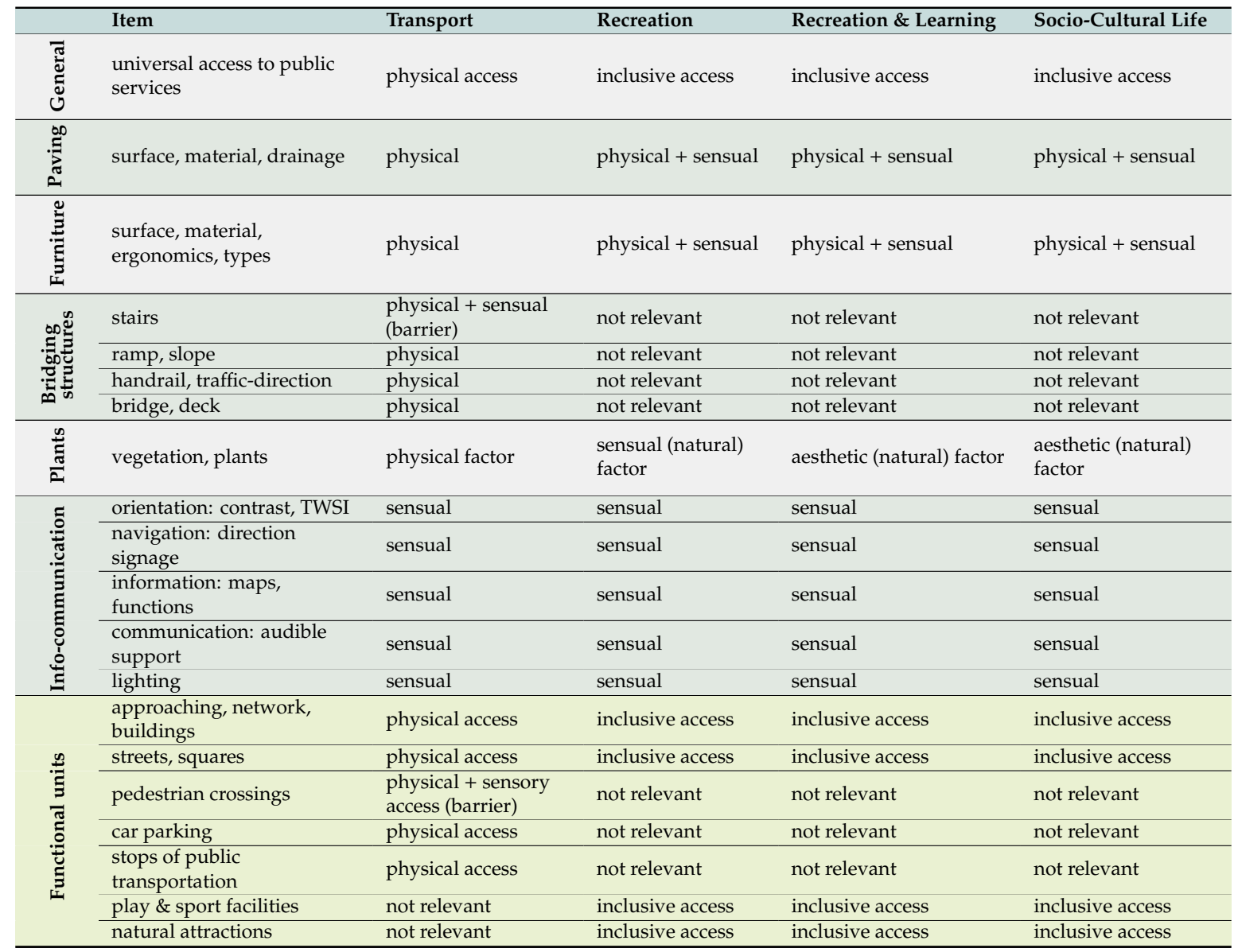




\section{References}

1. United Nations. World Urbanization Prospects 2018; ST/ESA/SER.A/421; United Nations: New York, NY, USA, 2019.

2. Gehl, J. Life between Buildings: Using Public Space, 6th ed.; Island Press: Washington, DC, USA, 2011.

3. Lynch, K. The Image of the City; The MIT Press: Cambridge, MA, USA, 1960.

4. Ward Thompson, C. Urban Open Space in the 21st Century. Landsc. Urban Plan. 2002, 60, 59-72. [CrossRef]

5. Koppen, G.; Sang, Å.O.; Tveit, M.S. Managing the Potential for Outdoor Recreation: Adequate Mapping and Measuring of Accessibility to Urban Recreational Landscapes. Urban For. Urban Green. 2014, 13, 71-83. [CrossRef]

6. Fekete, A.; Szaszák, G.; Szöbölödi, A.; Takács, D. General principles of barrier-Street furniture, motorized traffic, parking based on the example of downtown of Budapest = Egyetemes szabatértervezés Budapest belvárosában-Berendezési tárgyak, jármúközlekedés, parkolás. 4D Tájépitészeti És Kertmúvészeti F. 2012, 25, 41-59.

7. Balogh, P.I. The Change of Open Space Functions in the European Urban Renewal [A szabadterek szerepváltozása a nagy európai városmegújításokban]. Ph.D. Thesis, Corvinus University of Budapest, PhD School of Landscape Architecture and Decision Supporting Systems, Budapest, Hungary, 2004.

8. Szilágyi, K.; Almási, B.; Hutter, D.; Szabó, L. A várostervezés szürke-Zöld dilemmái. A városi térszerkezet alakítása és az élhető város elve [Gray-Green dilemmas of urban planning. Shaping the structure of urban space and the principle of a livable city]. In Fenntartható fejlődés, élhetö régió, élhető telepuilési táj; Szenteleki, K., Szilágyi, K., Eds.; Budapesti Corvinus Egyetem: Budapest, Hungary, 2012; Volume 1, pp. 205-226.

9. Kraus, L.; Lauer, L.; Coleman, R.; Houtenville, A. 2017 Disability Statistics Annual Report; University of New Hampshire, Institute on Disability: Durham, UK, 2018.

10. de Oliveira Neto, J.S. Inclusive Smart Cities: Theory and Tools to Improve the Experience of People with Disabilities in Urban Spaces. Ph.D. Thesis, Escola Politécnica da Universidade de Sao Paulo, Sao Paulo, Brazil, 2018.

11. de Oliveira Neto, J.S.; Kofuji, S.T. Inclusive Smart City: An Exploratory Study. In Universal Access in Human-Computer Interaction. Interaction Techniques and Environments; Antona, M., Stephanidis, C., Eds.; Springer International Publishing: Cham, Germany, 2016; pp. 456-465.

12. de Oliveira Neto, J.S.; Kofuji, S.T.; Bourda, Y. People with Disabilities' Needs in Urban Spaces as Challenges towards a More Inclusive Smart City. In Information Technology and Systems; Springer: Cham, Germany, 2020.

13. European Landscape Convention; Explanatory report ETS 176; Council of Europe: Florence, Italy, 2000.

14. Foth, M.; Hee-jeong Choi, J.; Satchell, C. Urban Informatics. In Proceedings of the 2011 ACM Conference on Computer Supported Cooperative Work, Hangzhou, China, 19-23 March 2011.

15. Ruchinskaya, T.; Ioannidis, K.; Kimic, K. Revealing the Potential of Public Places: Adding a New Digital Layer to the Existing Thematic Gardens in Thessaloniki Waterfront. In CyberParks-The Interface Between People, Places and Technology: New Approaches and Perspectives; Smaniotto Costa, C., Šuklje Erjavec, I., Kenna, T., de Lange, M., Ioannidis, K., Maksymiuk, G., de Waal, M., Eds.; Springer International Publishing: Cham, Germany, 2019; pp. 181-195. [CrossRef]

16. WHO. World Report on Disability; World Health Organization: Geneva, Switzerland, 2011.

17. United Nations. Convention on the Rights of Persons with Disabilities (CRPD); United Nations: New York, NY, USA, 2006.

18. ISO/FDIS. Building Construction-Accessibility and Usability of the Built Environment; International Standard (final draft) ISO/FDIS 21542:2011; ISO: Geneva, Switzerland, 2011.

19. United States. 2010 ADA Standards for Accessible Design; Technical standard; Department of Jusctice: Washington, DC, USA, 2010.

20. CEN-CENELEC. Guide for Addressing Accessibility in Standards; Guide CEN-CENELEC Guide 6:2002; European Committee for Standardization, European Committee for Electrotechnical Standardization: Brussels, Belgium, 2014.

21. Zöld, A. (Ed.) AWARD—Accessible World for All Respecting Differences; Lifelong Learning Program, Leonardo Da Vinci Project; Technical guide for higher education 07/0227-L/LLP-LdV-TOI-2007-HU_001 “AWARD”; Budapest University of Technology and Economics: Budapest, Hungary, 2009. 
22. Ruttkay-Miklián, Á. A Befogadó Tér. Belsőépítészet És Akadálymentesség [Inclusive Space. Interior Design and Accessibility]. In KÉZIKÖNYV-Az akadálymentesség és egyetemes tervezés müszaki-tervezői szempontjai, követelményei; Pandula, A., Ed.; FSZK: Budapest, Hungary, 2009.

23. Lundell, Y. Access to the Forests for Disabled People; Rolison, N., Translator; Report BEST NR 1678; Swedish National Board of Forestry: Jönköping, Sweden, 2005.

24. Prónay, B. A Fizikai És Infokommunikációs Akadálymentesítés Szakmai Hátterének Kialakítása-Az Alapok-Képességek Kompenzálási Lehetőségei: Látás [Developing a Professional Background for Physical and Infocommunication Accessibility-The Basics-Compensation of Disabilities: Vision]. In KÉZIKÖNYV-Az Akadálymentesség És Egyetemes Tervezés Müszaki-Tervezői Szempontjai, Követelményei; Pandula, A., Ed.; FSZK: Budapest, Hungary, 2009.

25. Dúll, A. Helyek, Tárgyak, Viselkedés. Környezetpszichológiai Tanulmányok [Places, Objects, Behavior. Environmental Psychological Studies]; Budapest University of Technology and Economics, Department of Sociology and Communication: Budapest, Hungary, 2010.

26. Ståhl, A.; Almén, M.; Wemme, M. Att Orientera Med Hjälp Av Ledytor-Blinda Testar Taktiliteten I Ytor Med Olika Material Och Struktur; Lunds Tekniska Högskola: Lund, Sweden, 2004.

27. Ståhl, A.; Newman, E.; Dahlin-Ivanoff, S.; Almén, M.; Iwarsson, S. Detection of Warning Surfaces in Pedestrian Environments: The Importance for Blind People of Kerbs, Depth, and Structure of Tactile Surfaces. Disabil. Rehabil. 2010, 32, 469-482. [CrossRef] [PubMed]

28. Kim, D.S.; Emerson, R.W.; Curtis, A. Drop-off Detection with the Long Cane: Effects of Different Cane Techniques on Performance. J. Vis. Impair. Blind. 2009, 103, 519-530. [CrossRef] [PubMed]

29. Kim, D.S.; Emerson, R.W. Effect of Cane Technique on Obstacle Detection with the Long Cane. J. Vis. Impair. Blind. 2014, 108, 335-340. [CrossRef]

30. Lauria, A. Tactile Pavings and Urban Places of Cultural Interest: A Study on Detectability of Contrasting Walking Surface Materials. J. Urban Technol. 2017, 24, 3-33. [CrossRef]

31. Magyar Vakok és Gyengénlátók Országos Szövetsége [Hungarian Federation of the Blind and Partially Sighted]. Állásfoglalás a Magyarországon Közforgalmú Területen Használható, Közlekedést Segítő Taktilis Jelek Alkalmazhatóságáról [Tactile Walking Surface Indicators Following ISO/FDIS23599:2012]; Resolution (International standard); MVGYOSZ: Budapest, Hungary, 2016.

32. Childs, C.; Tyler, N. Walking and Stopping over Tactile Paving. In Seamless Access for All: Universal Design in Transport Systems and Built Infrastructure, A Key Element in the Creation of Livable Cities; TRANSED: New Delhi, India, 2012.

33. Downey, C. Design with the Blind in Mind / TED Talk. Available online: https://www.ted.com/talks/chris_ downey_design_with_the_blind_in_mind (accessed on 2 May 2018).

34. Block, M.E.; Block, V.E.; Halliday, P. What Is Autism? Teach. Elem. Phys. Educ. 2006, 17, 7-11.

35. Radványi, K. A Fizikai És Infokommunikációs Akadálymentesítés Szakmai Hátterének Kialakítása-Az Alapok-Képességek Kompenzálási Lehetőségei: Kognitív Képességek [Developing a Professional Background for Physical and Infocommunication Accessibility-The Basics-Compensation of Cognitive Disabilities]. In KÉZIKÖNYV—Az Akadálymentesség És Egyetemes Tervezés Müszaki-Tervezői Szempontjai, Követelményei; Pandula, A., Ed.; FSZK: Budapest, Hungary, 2009.

36. Keresztessy, É. A Fizikai És Infokommunikációs Akadálymentesítés Szakmai Hátterének Kialakítása-Az Alapok—Képességek Kompenzálási Lehetőségei: Hallás [Developing a Professional Background for Physical and Infocommunication Accessibility-The Basics—Compensation of Disabilities: Hearing]. In KÉZIKÖNYV-Az Akadálymentesség És Egyetemes Tervezés Müszaki-Tervezői Szempontjai, Követelményei; Pandula, A., Ed.; FSZK: Budapest, Hungary, 2009.

37. Aspinall, P.; Bell, S.; Ward Thompson, C. (Eds.) Innovative Approaches to Research Excellence in Landscape and Health: Conference Proceedings, Summary Papers and Poster Abstracs, Edinburgh, 2007; Open Space-People Space; OPENspace Research Centre: Edinburgh, UK, 2007.

38. Ormerod, M.; Newton, R.; MacLennan, H.; Faruk, M.; Thies, S.; Kenney, L.; Howard, D.; Nester, C. Older People's Experiences of Using Tactile Paving. In Municipal Engineer; Thomas Telford Ltd.: London, UK, 2015.

39. Kálmán, Z.; Könczei, G. A Taigetosztól az Esélyegyenlőségig [From Taigetos to Equal Opportunities]; Osiris: Budapest, Hungary, 2002. 
40. Degener, T. A New Human Rights Model of Disability. In The United Nations Convention on the Rights of Persons with Disabilities: A Commentary; Della Fina, V., Cera, R., Palmisano, G., Eds.; Springer International Publishing: Cham, Germany, 2017; pp. 41-59. [CrossRef]

41. Szaszák, G. Egyetemes Szabadtértervezés [Universal Open Space Design]; Szent István Egyetem: Budapest, Hungary, 2018.

42. Patrão, C.; Moura, P.; de Almeida, A.T. Review of Smart City Assessment Tools. Smart Cities 2020, 3, 1117-1132. [CrossRef]

43. Brilhante, O.; Klaas, J. Green City Concept and a Method to Measure Green City Performance over Time Applied to Fifty Cities Globally: Influence of GDP, Population Size and Energy Efficiency. Sustainability 2018, 10, 2031. [CrossRef]

44. Szilágyi, K.; Balogh, P.I.; Fekete, A.; Veréb, M. A Városliget Parkhasználati Felmérése [The Budapest City Park's Use Survey]; parkhasználati felmérés; Budapesti Corvinus Egyetem Kert-és Szabadtértervezési Tanszéke, Ormos Imre Alapítvány: Budapest, Hungary, 2014.

45. Maller, C.; Townsend, M.; Pryor, A.; Brown, P.; St Leger, L. Healthy Nature Healthy People: "contact with Nature" as an Upstream Health Promotion Intervention for Populations. Health Promot. Int. 2006, 21, $45-54$. [CrossRef] [PubMed]

46. Ottoson, J. The Importance of Nature in Coping. Creating Increased Understanding of the Importance of Pure Experiences. Ph.D. Thesis, Swedish University of Agricultural Sciences, Alnarp, Sweden, 2007.

47. Bertram, C.; Rehdanz, K. The Role of Urban Green Space for Human Well-Being. Ecol. Econ. 2015, 120, 139-152. [CrossRef]

48. Skärbäck, E.; Wadbro, J.; Björk, J.; Jong, K.; Albin, M.; Ardö, J.; Grahn, P. The Agricultural Landscape for Recreation; IntechOpen: London, UK, 2012. [CrossRef]

49. Petríková, D.; Petríková, L. Inclusive and Accessible SMART City for All. In Smart Governance for Cities: Perspectives and Experiences; Lopes, N.V.M., Ed.; EAI/Springer Innovations in Communication and Computing; Springer International Publishing: Cham, Germany, 2020.

50. Komninos, N. Smart Cities. In The SAGE Encyclopedia of the Internet; Warf, B., Ed.; SAGE Publications, Inc.: Thousand Oaks, CA, USA, 2020; pp. 783-789. [CrossRef]

51. Accessibility Design Guide: Universal Design Principles for Australia's Aid Program; Registration Nr. 13; Australian Government's AusAID: Canberra, Australia, 2013.

52. Elgendy, M.; Sik Lanyi, C. Review on Smart Solutions for People with Visual Impairment. In Computers Helping People with Special Needs; Miesenberger, K., Kouroupetroglou, G., Eds.; Springer International Publishing: Cham, Germany, 2018; pp. 81-84.

53. Real, S.; Araujo, A. Navigation Systems for the Blind and Visually Impaired: Past Work, Challenges, and Open Problems. Sensors 2019, 19, 3404. [CrossRef] [PubMed]

54. Pak, B. ICT-Enabled Bottom-Up Architectural Design. Int. J. Archit. Res. ArchNet-IJAR Online 2016, 10, $26-40$. [CrossRef]

55. Namsill, D. Frank Lloyd Wright Interview; University of Chicago Press: Chicago, IL, USA, 1998.

56. Kecskés, T. A spontán-Avagy az akaratlan építészeti formálás természetrajza [The Nature of Spontaneous Architectural Creation]. Ph.D. Thesis, Moholy-Nagy University of Arts and Design, Budapest, Hungary, 2012.

57. Kroll, L. The Architecture of Complexity; Blundell Jones, P., Translator; MIT Press: Cambridge, MA, USA, 1987.

58. Ward Thompson, C.; Travlou, P. (Eds.) Open Space: People Space, 1st ed.; Taylor \& Francis: Abingdon, UK; New York, NY, USA, 2007.

59. MacPherson, H.M. Landscapes of Blindness and Visual Impairment: Sight, Touch and Laughter in the English Countryside. Ph.D. Thesis, Newcastle University, Newcastle, UK, 2007.

60. Kylin, M.; Sternudd, C.; Wood, L. Round Balls in Square Holes-Urban Planning from a Child's Perspective. In The Power of Landscape; European Council of Landscape Architecture Schools (ECLAS): Warsaw, Poland, 2012. Available online: http://eclas2012.sggw.pl/web-eclas12. pdf?fbclid=IwAR0rfOllxLCpmatKucF6fduIQ0wtN8W8xJ6t6aDPx6s5WY1OZWQMrAeIlqA (accessed on 10 November 2020).

61. Hungarian Act on the Formation and Protection of the Built Environment; FAO: Rome, Italy, 1997.

62. Hungarian Act XXVI of 1998 on the Equalization of Opportunity; Magyar Közlöny: Budapest, Hungary, 1998. 
63. Hungarian Government Decree on the National Settlement Planning and Construction Requirements (OTÉK); European Union: Brussels, Belgium, 1997.

64. Nijhuis, S.; de Vries, J. Design as Research in Landscape Architecture. Landsc. J. 2019, 38, 87-103. [CrossRef]

65. Herriott, R. What Kind of Research Is Research through Design? In Design Revolutions; Manchester School of Art, Manchester Metropolitan University: Manchester, UK, 2019.

66. Francis, M. A Case Study Method for Landscape Architecture. Landsc. J. 2001, 20, 1-19. [CrossRef]

67. Fekete, A.; Koszorú, L.; Zöldi, P. Budapest Szíve: Reprezentatív Kaputérség-Károly Körút, Astoria Csomópont, Deák Ferenc Tér, Bajcsy-Zsilinszky Út, József Attila Utca, És Kapcsolódó Közterületek Megújítása [Heart of Budapest: A Representative Gateway Renewal of Károly Road, Astoria Junction, Deák Ferenc Square, Bajcsy Zsilinszky Road, József Attila Street and Adjoining Public Spaces]. 4D J. Landsc. Archit. Gard. Art 2009, 13, 3-13.

68. Szaszák, G. Akadálymentes városi utcák és közterek-Eegy belvárosi utcaszakasz rehabilitációs környezetrendezési terve. Mintaterület: A Károly körút Astoria és Deák tér közti szakasza [Barrier-free Public Open Spaces-A Rehabilitation Landscaping Plan for the Downtown of Budapest. Sample Area: The Section of Károly körút between Astoria and Deák tér]. Master's Thesis, Budapest University of Technology and Economics, Budapest, Hungary, 2010.

69. s73 Landscape Architects. Belváros új főutcája [The New Main Street of Pest]. Des. Portf. 2010. Available online: https://www.s73.hu/belvaros-uj-foutcaja (accessed on 5 October 2020).

70. Szaszák, G. Budapest Szíve Városfejlesztési Program, Reprezentatív Kaputérség Kiépítése, I. Ütem/Tájépítészeti Munkarész/Akadálymentesítési Tervfejezet (Diplomamunka). Az Egyetemes Tervezés Követendő Példája-Nyertes Pályamunka 1. [The Heart of Budapest Urban Development Program, Construction of a Representative Gate Area, Phase I/Landscape Architecture/Accessibility Plan (Master's Thesis). Good Practice of Universal Design-1st Prize]. In Egyetemes Tervezés-Jó Példák Tára [Universal Design—Library of Good Practices]; Szabó, H., Ed.; Mozgássérültek Budapesti Egyesülete Egyetemes Tervezés Információs és Kutatóközpont (ETIKK): Budapest, Hungary, 2018; pp. 14-19.

71. Magyar Vakok és Gyengénlátók Országos Szövetsége [Hungarian Federation of the Blind and Partially Sighted]. Állásfoglalás a Gyalogos Forgalomirányító Lámpák Akadálymentességére Vonatkozó Irányelvekről [Audible Traffic Signals at Pedestrian Crossings]; Resolution; MVGYOSZ: Budapest, Hungary, 2012.

72. Bazsó, G.; Szikra, É. Budapest, Városliget Történeti Kert [The Budapest City Park Historic Garden]; Kulturális Örökségvédelmi Hivatal: Budapest, Hungary, 2012.

73. Szilágyi, K.; Veréb, M. The City Park's 200 Years-Changes in Spatial Structure and Park Use in the Life of an Urban Park = A Városliget 200 Éve-Térszerkezeti És Parkhasználati Változások Egy Városi Park Életében. 4D J. Landsc. Archit. Gard. Art 2013, 33, 20-45.

74. Városliget Zrt. Liget Budapest Project. Liget Budapest. Available online: https://ligetbudapest.hu/en/aboutthe-project (accessed on 5 October 2020).

75. Fekete, A.; Sárospataki, M.; Csonka, Z.; Jánoska, R.Z. Joseph Paxton's Approach to Historical City Park Design in the 21st Century. Czas. Tech. 2016, 2016, 111-124.

76. Ward Thompson, C. Historic American Parks and Contemporary Needs. Landsc. J. 1998, 17, 1-25. [CrossRef]

77. Bardóczi, S. Kakukktojások? [Odd-one-outs?] epiteszforum.hu. 2009. Available online: http://epiteszforum. hu/kakukktojasok (accessed on 8 May 2018).

78. Garten Studio. Városliget Park Competition. Design Portfolio. 2016. Available online: https: //gartenstudio.hu/en/projects/category/show\#V\%C3\%A1rosliget\%20tervp\%C3\%A1ly\%C3\%A1zat, V\%C3\%A1rosliget\%20park\%20competition (accessed on 8 May 2018).

79. Garten Studio. Liget Park Fórum egyeztető tárgyalás a vakok és gyengén látók szervezeteivel [Liget Park Forum Conciliation Meeting with Organizations of the Blind and Visually Impaired]. 26 October 2016. Available online: http://www.varosligetpark.hu/wp-content/uploads/2016/11/PAR_JK_TE-Latasser\%C3\% BCltek_R00_20161026jelenleti-alairt.pdf (accessed on 8 May 2018).

80. Garten Studio. Liget Park Fórum egyeztető tárgyalás mozgássérült és fogyatékos embereket képviselő szervezetekkel [Liget Park Forum Conciliation Meeting with Organizations of People Living with Mobility Impairments and Other Disabilities]. 23 November 2016. Available online: http://www.varosligetpark. hu/http://www.varosligetpark.hu/wp-content/uploads/2016/11/PAR_JK_TE-MS_R00_20161123jelenletiiv.pdfwp-content/uploads/2016/11/PAR_JK_TE-Latasser\%C3\%BCltek_R00_20161026jelenleti-alairt.pdf (accessed on 8 May 2018). 
81. Parti, M.; Melles, F. (Eds.) Liget Akadálymentesítési Koncepció [Liget Accessibility Concept]; Akadálymentesítési koncepció; Technical Guidelines; Liget Mérnök Konzorcium: Budapest, Hungary, 2016.

82. Vincze, A. A vízé a főszerep-A Pagony Iroda 3. díjas terve [Water plays the main role-The 3rd Prize Plan of Pagony Landscape Architects]. epiteszforum.hu. 2016. Available online: https://epiteszforum.hu/a-vize-afoszerep-a-pagony-iroda-3-dijas-terve (accessed on 8 May 2018).

83. Ruttkay-Miklián, Á.; Szaszák, G. A Városliget, Mint PARK Akadálymentességi Koncepciója [The Budapest City PARK's Accessibility Concept]; Városliget park rehabilitáció tervezési program [Budapest City Park Planning Concept Program]; Planning concept program; Garten Studio: Budapest, Hungary, 2017.

84. T-WALK Taktilis Burkolat Rendszer [T-WALK Tactile Paving System]. Available online: https:// csuszasgatloszalag.hu/termekeink/taktilis-vezetosav (accessed on 17 October 2020).

85. Hungarian Act No. LIII. of 1996 on Nature Conservation. Available online: https://www.asser.nl/upload/eelwebroot/www/documents/HUN/hungary\%20Nature\%20Conservation\%20law.htm (accessed on 3 May 2018).

86. Skuleskogen National Park | Choose National Park | Sweden's National Parks. Available online: http://www. nationalparksofsweden.com/choose-park---list/skuleskogen-national-park/ (accessed on 17 October 2020).

87. Söderåsen National Park. Available online: https://visitskane.com/outdoors-adventure/soderasen-nationalpark (accessed on 17 October 2020).

88. Tillgänglighet. Available online: https://skrylle.se/tillganglighet/ (accessed on 17 October 2020).

89. Városliget Zrt. SMART LIGET: Digitális Megoldások a Látogatói Élmény És a Fenntarthatóság Szolgálatában [SMART LIGET: Digital Solutions for Visitor Experience and Sustainability]. Liget Budapest. Available online: https://www.hte.hu/documents/10180/4050550/4_4_MJIK2017_Petrik.pdf (accessed on 10 May 2018).

Publisher's Note: MDPI stays neutral with regard to jurisdictional claims in published maps and institutional affiliations.

(C) 2020 by the authors. Licensee MDPI, Basel, Switzerland. This article is an open access article distributed under the terms and conditions of the Creative Commons Attribution (CC BY) license (http://creativecommons.org/licenses/by/4.0/). 